\title{
Ultrastructure of laevigate hilate spores in sporangia and spore masses from the Upper Silurian and Lower Devonian of the Welsh Borderland
}

\author{
Gharles H. Wellman', Dianne Edwards ${ }^{2}$ and Lindsey Axe ${ }^{2}$ \\ ${ }^{1}$ Centre for Palynology, University of Sheffield, Dainton Building, Brook Hill, Sheffield S3 7HF, UK \\ ${ }^{2}$ Department of Earth Sciences, Cardiff University, PO Box 914, Cardiff CF1 3YE, UK
}

CONTENTS

PAGE

1. Introduction

1984

2. Localities, techniques and material

1984

(a) Locality data

(b) Techniques

(c) Material

3. Hilate cryptospores and dyads: introduction and terminology

4. Laevolancis (Archaeozonotriletes) divellomedia (Chibrikova) Burgess \& Richardson 1991

5. Descriptions

(a) Group A (Ludford Lane)

(b) Group B (Ludford Lane)

(c) Group C (North Brown Clee Hill)

(d) Group D (North Brown Clee Hill)

(e) Group E (North Brown Clee Hill)

6. Spore identification

7. Comments on extra-exosporal material

8. Affinities

1984

1984

1985

1985

1986

1986

1986

1987

1988

1991

1993

1994

1997

1997

1997

(a) Plants with in situ dyads

1998

(b) Comparisons with spore wall ultrastructure and related characters in fosssil plants

1999

(c) Comparisons with spore wall ultrastructure and related characters in extant plants

(d) Conclusions

2000

2001

2002

2002

2002

2002

2002

2003

11. Conclusions

2003

Spore masses and isolated sporangia, containing laevigate hilate cryptospores attributable to the dispersed taxon Laevolancis divellomedia sensu lato, have been recovered on bulk maceration of Upper Silurian (Pridoli) and Lower Devonian (Lochkovian) deposits from the Welsh Borderland. Detailed morphological, anatomical and ultrastructural analysis, using light microscope, scanning electron microscope and transmission electron microscope techniques, reveals subtle differences between the specimens and they can be grouped into five distinct types. The different groups are distinguished principally by using sporangia-spore mass characteristics, presence or absence of extra-exosporal material and nature of spore wall ultrastructure. Of the groups, one has a uniformly homogeneous exospore and the other four groups have a bilayered exospore. In the former the spores lack extraexosporal material and occur in a discoidal sporangium. Of the bilayered groups, two have exospores of homogeneous composition but with the two layers differing in electron density. They occur in discoidal sporangia and spore masses and are distinguished on the presence or absence of extra-exosporal material and differences in the widths of the two layers. Finally, two bilayered groups possess a lamellate inner layer, but vary in presumed sporangial shape. Elongate sporangia have spores with concentric 
continuous lamellae, lacking further ultrastructure. In contrast, spores from a discoidal spore mass have white-line-centred, presumably tripartite, lamellae which are laterally discontinuous, overlapping and irregularly spaced. These findings, which suggest that morphologically similar spores were produced by a number of plant taxa, have important implications regarding the assessment of early land-plant diversity. The affinities of hilate cryptospore-producing plants are unknown and problematic, particularly as no extant non-angiosperm plants produce dyads, other than through meiotic irregularity, and sporesporangial characters have no exact counterpart in coeval plants. Studies of specimens with in situ hilate cryptospores suggest that they derive from rhyniophytoids, i.e. plants that resemble the simplest of vascular plants but lack evidence of vascular tissue, although hilate cryptospore-containing examples show no axial branching. It might be argued, based on evidence from spore wall ultrastructure, that some of the plants have more in common with lycopsids and filicopsids than bryophytes, a surprising finding bearing in mind the stratigraphic distribution of hilate cryptospores-dyads and inferences that the producers were bryophyte-like. Detailed studies of wall structure in the hilate cryptospores permit consideration of spore wall development. It is suggested that extra-exosporal material derives from a tapetum and is thus produced by the diploid sporophyte. The white-line-centred lamellae in a single specimen provide the earliest evidence for the presence of such structures in early land-plant spores and provide further evidence that sporopollenin deposition on such structures is the most primitive mode of sporopollenin deposition among land plants.

Keywords: Silurian; Devonian; early land plants; cryptospores; tapetum; ultrastructure

\section{INTRODUCTION}

Assemblages of exceptionally preserved fossils of early land plants have recently been discovered in uppermost Silurian and lowermost Devonian deposits of the Welsh Borderland (Edwards (1996) and references therein). Although coalified and semi-compressed, the fossils retain exquisite cellular detail of certain tissues, and are helping us to understand the affinities, phylogenetic relationships and many aspects of the palaeobiology of early land plants. Particularly informative are in situ spores which are useful in adding characters for the identification of plants with simple gross morphology and in comparisons with spores in coeval dispersed-spore assemblages. They thus permit integration of the plant megafossil and dispersed spore records such that terrestrial vegetation can be reconstructed from the extensive dispersed-spore record even in the absence of megafossils. In addition, analysis of the ultrastructure of in situ spores, by using transmission electron microscopy (TEM), provides information on the ontogeny and construction of the spores, as well as further taxonomic characters. In this paper we extend our TEM studies to sporangia and spore masses containing laevigate hilate cryptospores, most of which can be referred to the dispersed spore taxon Laevolancis (Archaeozonotriletes) divellomedia (Chibrikova) Burgess \& Richardson 1991 sensu lato.

\section{LOCALITIES, TECHNIQUES AND MATERIAL}

\section{(a) Locality data}

(i) Ludford Lane, Ludlow, Shropshire

The fossils were obtained from siltstone horizons $1.6 \mathrm{~m}$ and $1.8 \mathrm{~m}$ above the main bone bed at this famous locality. The productive horizons occur in a small cliff at the junction of Ludford Lane (Whitcliffe Road) and Leominster Road (A49), ca. $80 \mathrm{~m}$ SSW of Ludford Bridge, Ludlow (White \& Lawson 1989). The sediments belong to the Platyschisma Shale Member of the Downton Castle Formation. They are interpreted as 'silts formed offshore within wavebase' (Richardson \& Rasul 1990). Sporomorph assemblages from these horizons belong to the tripapillatusspicula Spore Assemblage Biozone (Richardson \& McGregor 1986) indicating a Pridoli (Late Silurian) age (Richardson \& Rasul 1990). Previous palaeobotanical studies include Jeram et al. (1990), Edwards et al. (1995a,d, 1996) and Edwards (1996).

\section{(ii) North Brown Clee Hill, Shropshire}

The fossils were obtained from a siltstone horizon exposed in a stream section on North Brown Clee Hill (Edwards et al. 1994). The sediments belong to the lower part of the Ditton Group (Ball \& Dineley 1961). They are interpreted as fluvial in origin. Sporomorph assemblages from this horizon belong to the middle subzone of the micrornatus-newportensis Sporomorph Assemblage Biozone (Richardson \& McGregor 1986) indicating an Early Lochkovian (Early Devonian) age (Edwards et al. 1994). Previous palaeobotanical studies include Edwards et al. (1986, 1992, 1994, 1995a-d), Fanning et al. (1988) and Edwards (1996).

\section{(b) Techniques}

The fossils were isolated by bulk acid maceration $(\mathrm{HCl}+\mathrm{HF})$ of the siltstones. Conventional procedures for preparation of palynological samples were employed, except that centrifugation was omitted. Specimens were air-dried, picked out under a dissecting microscope, mounted on stubs and coated for analysis by scanning electron microscopy (SEM). Following SEM analysis, specimens were removed from the stub, fractured using a fine needle, and prepared either for further SEM analysis and/or analysis using TEM and/or light microscopy (LM). All stubs, grids and slides are housed in the National Museum of Wales at Cardiff. Additional SEM images collected via a PC-based image capture and storage system are stored on hard disc (WORM) drive. Selected images have been transferred to CDROM (durable non fading format not subject to accidental erasure) which is deposited in the National Museum along with the specimens. Preparation and curation techniques are as described by Wellman et al. 
spore characters

\begin{tabular}{|c|c|c|c|c|c|c|c|c|}
\hline specimen and locality & description and dimensions & (1) size & (2) $\mathrm{AD}(3)$ & 3) EEM & (4) $\mathrm{P}$ & (5) $\mathrm{H}$ & (6) $\mathrm{CD}$ & (7) USG \\
\hline $\begin{array}{l}\text { (1) NMW97.1G.4 } \\
\text { Ludford Lane }\end{array}$ & $\begin{array}{l}\text { irregular spore mass } \\
600+\mu \mathrm{m}\end{array}$ & $18(21) 23 \mu \mathrm{m}-4$ & $\mathrm{R}$ & 0 & 0 & $\mathrm{x}$ & 0 & A \\
\hline (2) NMW97.1G.3 & irregular spore mass & $25(28) 31 \mu \mathrm{m}-6$ & $\mathrm{R}$ & 0 & 0 & $\mathrm{x}$ & 0 & A \\
\hline Ludford Lane & $800+\mu \mathrm{m}$ & & & & & & & \\
\hline $\begin{array}{l}\text { (3) NMW97.1G.5 } \\
\text { Ludford Lane }\end{array}$ & $\begin{array}{l}\text { irregular spore mass } \\
600+\mu \mathrm{m}\end{array}$ & $17(20) 26 \mu \mathrm{m}-6$ & $\mathrm{R}$ & 0 & 0 & $\mathrm{x}$ & 0 & A \\
\hline $\begin{array}{l}\text { (4) NMW96.11G.1 } \\
\text { Ludford Lane }\end{array}$ & $\begin{array}{l}\text { discoidal spore mass } \\
670 \mu \mathrm{m}\end{array}$ & $27(29) 32 \mu \mathrm{m}-7$ & $\mathrm{R}$ & 0 & 0 & $\mathrm{x}$ & 0 & A \\
\hline $\begin{array}{l}\text { (5) NMW97.1G.2 } \\
\text { Ludford Lane }\end{array}$ & $\begin{array}{l}\text { discoidal spore mass } \\
460 \mu \mathrm{m}\end{array}$ & $20(24) 30 \mu \mathrm{m}-7$ & $\mathrm{R}$ & 0 & 0 & $\mathrm{x}$ & 0 & A \\
\hline $\begin{array}{l}\text { (6) NMW96.30G.2 } \\
\text { Ludford Lane }\end{array}$ & $\begin{array}{l}\text { discoidal sporangium } \\
780 \mu \mathrm{m}\end{array}$ & $25(27) 29 \mu \mathrm{m}-7$ & $\mathrm{R}$ & 0 & 0 & $\mathrm{x}$ & 0 & A \\
\hline $\begin{array}{l}\text { Ludford Lane } \\
\text { (7) NMW97.1G.1 } \\
\text { Ludford Lane }\end{array}$ & $\begin{array}{l}\text { discoidal sporangium } \\
900 \mu \mathrm{m}\end{array}$ & $21(23) 25 \mu \mathrm{m}-6$ & $\mathrm{R}$ & 0 & 0 & $\mathrm{x}$ & 0 & A \\
\hline $\begin{array}{l}\text { (8) NMW96.11G.2 } \\
\text { Ludford Lane }\end{array}$ & $\begin{array}{l}\text { elongate sporangium } \\
1470+\text { by } 345+\mu \mathrm{m}\end{array}$ & $26(29) 32 \mu \mathrm{m}-6$ & $\mathrm{R}$ & 1 & 1 & 0 & 0 & B \\
\hline $\begin{array}{l}\text { (9) NMW96.30G.3 } \\
\text { Ludford Lane }\end{array}$ & $\begin{array}{l}\text { elongate sporangium } \\
1960+\text { by } 280+\mu \mathrm{m}\end{array}$ & $26(28) 29 \mu \mathrm{m}-10$ & $\mathrm{R}$ & 1 & 1 & 0 & 0 & B \\
\hline $\begin{array}{l}\text { (10) NMW96.30G.5 } \\
\text { North Brown Clee Hill }\end{array}$ & $\begin{array}{l}\text { discoidal spore mass } \\
740 \mu \mathrm{m}\end{array}$ & $34(36) 40 \mu \mathrm{m}-10$ & $\mathrm{R}$ & 2 & 2 & 0 & 0 & $\mathrm{C}$ \\
\hline $\begin{array}{l}\text { (11) NMW96.30G.6 } \\
\text { North Brown Clee Hill }\end{array}$ & $\begin{array}{l}\text { discoidal sporangium } \\
780 \mu \mathrm{m}\end{array}$ & $49(53) 59 \mu \mathrm{m}-10$ & $\mathrm{C}$ & 0 & 0 & 0 & 0 & $\mathrm{D}$ \\
\hline $\begin{array}{l}\text { (12) NMW96.30G.4 } \\
\text { North Brown Clee Hill }\end{array}$ & $\begin{array}{l}\text { discoidal sporangium } \\
1640 \mu \mathrm{m}\end{array}$ & $24(32) 39 \mu \mathrm{m}-10$ & $\mathrm{R}$ & 3 & 0 & 0 & $\mathrm{x}$ & $\mathrm{E}$ \\
\hline $\begin{array}{l}\text { (13) NMW97.1 G.6 } \\
\text { North Brown Clee Hill }\end{array}$ & $\begin{array}{l}\text { discoidal sporangium } \\
1400 \mu \mathrm{m}\end{array}$ & $30(33) 42 \mu \mathrm{m}-10$ & $\mathrm{R}$ & 3 & 0 & 0 & $\mathrm{x}$ & $\mathrm{E}$ \\
\hline
\end{tabular}

Regarding spore characters: (1) size refers to maximum spore diameter (smallest(mean)largest-number of specimens measured);

(2) AD refers to abundance of intact dyads where $\mathrm{C}$, common and $\mathrm{R}$, rare; (3) EEM refers to occurrence of extra-exosporal material where 0 , absent; 1 , type 1 ; 2, type 2; 3, type 3; (4) P refers to occurrence of puckering in the region of the curvaturae where 0 , absent; 1, type 1; 2, type 2; (5) $\mathrm{H}$ refers to occurrence of characteristic holes where 0 , absent and $\mathrm{X}$, present; (6) CD refers to occurrence of characteristic degradation where 0 , absent and X, present; (7) USG refers to ultrastructure group (groups A-E).

(1996). TEM techniques follow those of Rogerson et al. (1993) and Edwards et al. (1995a,c, 1996). Both unoxidized and oxidized (ten minutes in concentrated nitric acid) material was examined unstained and stained (ten minutes uranyl acetate followed by five minutes in lead citrate). All sections were cut by using a diamond knife. Spores were isolated from the specimens for LM analysis by physically breaking the specimens apart using a fine needle and oxidizing them in concentrated nitric acid $(10 \mathrm{~min})$. While the isolated spores provide some idea of the appearance of dispersed spores derived from these specimens, it must be remembered that the isolation techniques are harsh and involve oxidation, such that the appearance of the spores may have been altered.

\section{(c) Material}

Spore masses and isolated sporangia (i.e. masses with surrounding tissue) containing spores attributable to L. divellomedia sensu lato are relatively common at Ludford Lane and North Brown Clee Hill. The spore masses are either discoidal (perhaps complete) or irregular (probably broken). The sporangia are either discoidal or, more rarely, elongate. A total of 13 specimens have been examined ultrastructurally and are described here: nine are from Ludford Lane and four from North Brown Clee Hill (details in table 1).

\section{HILATE CRYPTOSPORES AND DYADS: INTRODUCTION AND TERMINOLOGY}

Hilate cryptospores are monads that are believed to be the separated products of dyads. They are characterized by a more or less circular contact area (hilum) situated on the proximal surface. The contact area is delimited by an equatorial-to-subequatorial curvatura that usually comprises a thickening (crassitude) and sometimes marks a change in ornament. It thus clearly marks the position of contact with the other spore in the dyad. The exospore in the contact area is usually thinner than that of the remainder of the spore. The contact area and the exospore outside the contact area may be laevigate or ornamented. Where ornamentation is present, that over the contact area and outside the contact area usually differs. For terminology used in the description of hilate cryptospores see Richardson (1996a). Undisputed separated hilate cryptospores are first reported in the Early Wenlock (Burgess \& Richardson 1991), and increase in abundance throughout the Silurian and earliest Devonian. However, possible hilate cryptospores occur in the 
Caradoc, although many of these are believed to have been physically torn out of permanent dyads (Wellman 1996). The abundance of hilate cryptospores diminishes rapidly after the Lochkovian although they persist until at least the Late Devonian.

Undissociated dyads, i.e. those that have not separated and are dispersed intact, also occur in assemblages of dispersed spores (Strother 1991; Richardson 1996a; Wellman 1996). They may be naked or enclosed within an envelope. Such dyads are common from the LlanvirnLlandovery. However, following the Llandovery they decrease in abundance and envelope-enclosed forms become extremely rare. The youngest undissociated dyads are recorded in the Lochkovian (Wellman 1993a). Undissociated dyad-hilate cryptospore abundance appears to show an inverse relationship. Following their appearance in the Early Wenlock hilate cryptospore abundance rapidly increases as undissociated dyad abundance diminishes. The affinities of the undissociated dyads and their relationship to hilate cryptospore-producing plants is unclear and is discussed here.

\section{LAEVOLANCIS (ARCHAEOZONOTRILETES) DIVELLOMEDIA (CHIBRIKOVA) BURGESS \& RICHARDSON 1991}

Laevolancis (Archaeozonotriletes) divellomedia (Chibrikova) Burgess \& Richardson 1991 was first described as Archaeozonotriletes divellomedium by Chibrikova (1959). It has subsequently been widely reported from the Wenlock to the Frasnian. However, because the nature of the proximal face was unclear, it has been placed, often using open nomenclature, with a number of different genera (see synonymy list in Burgess \& Richardson (1991)). After it was recognized that many Ordovician-Early Devonian spores were associated in dyads, and the concept of hilate cryptospores was established, these spores were placed in the new genus Laevolancis Burgess \& Richardson 1991 (Burgess \& Richardson 1991; Strother 1991; Richardson 1996a). The generic diagnosis is Alete proximally hilate cryptospores, originally elliptical to hemispherical in equatorial view with an equatorial-to-subequatorial crassitude surrounding the hilum; exine laevigate'. (Burgess \& Richardson 1991). L. divellomedia is distinguished from the only other described species (L. plicata Burgess \& Richardson 1991) because it is slightly larger, more inflated distally and has a thicker, more rigid, wall. However, more detailed scrutiny of such laevigate azonate forms in dispersed assemblages will undoubtedly lead to further subdivision of $L$. divellomedia (Richardson $1996 b$; J. B. Richardson, personal communication). Hence we use sensu lato here.

Burgess \& Richardson (1991) noted that L. divellomedia is '. . occasionally seen as loosely attached dyads' and they '... are all alete and many, if not all, are derived from dyads'. Assemblages of dispersed spores containing $L$. divellomedia often also contain dyads the constituents of which appear to belong to L. divellomedia but which uncharacteristically have failed to dissociate. Such dyads can be accommodated in the taxon Dyadospora murusdensa Strother \& Traverse emend. Burgess \& Richardson 1991 sensu lato. However, dyads attributed to D. murusdensa are known from at least the Llanvirn which is earlier than the first reported L. divellomedia. It thus seems likely that $D$. murusdensa sensu lato may incorporate a number of biologically distinct spore taxa that derive from plants that are not necessarily closely related.

\section{DESCRIPTIONS}

Detailed examination of the specimens (SEM, TEM and LM) suggests that they can be divided into five groups (groups $\mathrm{A}-\mathrm{E}$ ) (see tables 1 and 2). For convenience the following descriptions are arranged by using these groups. Terminology used in description of spore wall ultrastructure follows that adopted by Rogerson et al. (1993) and Edwards et al. (1995a,c, 1996). A total of five basic types of ultrastructure corresponding to the five groups $\mathrm{A}-\mathrm{E}$ have been recognized (table 2).

\section{(a) Group A (Ludford Lane)}

(Figures $1 c-i, 2$ and 3.)

\section{(i) SEM observations}

A total of five spore masses are either discoidal (possibly entire) or irregular (probably broken) in shape and are 460$800 \mu \mathrm{m}$ in maximum diameter (figures $1 d-f, h-i$ and $2 c, d$, $h-l)$. The spores resemble typical $L$. divellomedia and are remarkably constant in size both within and between specimens (see table 1). The spores predominantly occur dissociated, but occasionally as loose dyads. There is little or no extra-exosporal material (EEM) present on or between spores. In all of these masses some of the spores contain small holes (figures $2 h-l, 3 j$ ). The holes are rounded with bevelled edges. They are $c a .1 .5 \mu \mathrm{m}$ in diameter at the surface of the spore, but are stepped in that they abruptly constrict to $c a .1 \mu \mathrm{m}$ deeper in the exospore. The holes occur on both proximal and distal surfaces but are irregular in their distribution among and on spores. The number of holes on individual spores varies from 0 to 13 and they may be closely spaced or widely separated, and in some cases overlap.

There are two discoidal sporangia (NMW97.1G.1 and NMW96.30G.2), 900 and $780 \mu \mathrm{m}$ in maximum diameter, respectively, that have an external surface comprising a laevigate and featureless sheet here interpreted tentatively as a sporangial cuticle (figures $1 c, g$ and $2 a, b, e-g$ ). The internal surface of the sheet is not exposed. The spores are attributable to L. divellomedia. They are uniform in size and are predominantly dissociated with a few dyads. There is little or no EEM present on or between the spores. Some of the spores possess the characteristic holes present in the spores comprising the masses described here.

\section{(ii) TEM observations}

The spore masses all have a bilayered wall in which a more electron-dense outer layer usually surrounds a less electron-dense inner layer, although reverse staining may occur (see Edwards et al. 1995a, p.162) (figure 3a-e, gh). The outer layer appears to be consistently slightly wider $(c a .10-20 \%)$ than the inner layer. The layering is discernible in unstained sections but is much more obvious in stained sections where stain is preferentially taken up, usually by the outer layer. The sections confirm that there is very little EEM on and between spores in the spore masses. In rare cases the holes in the 


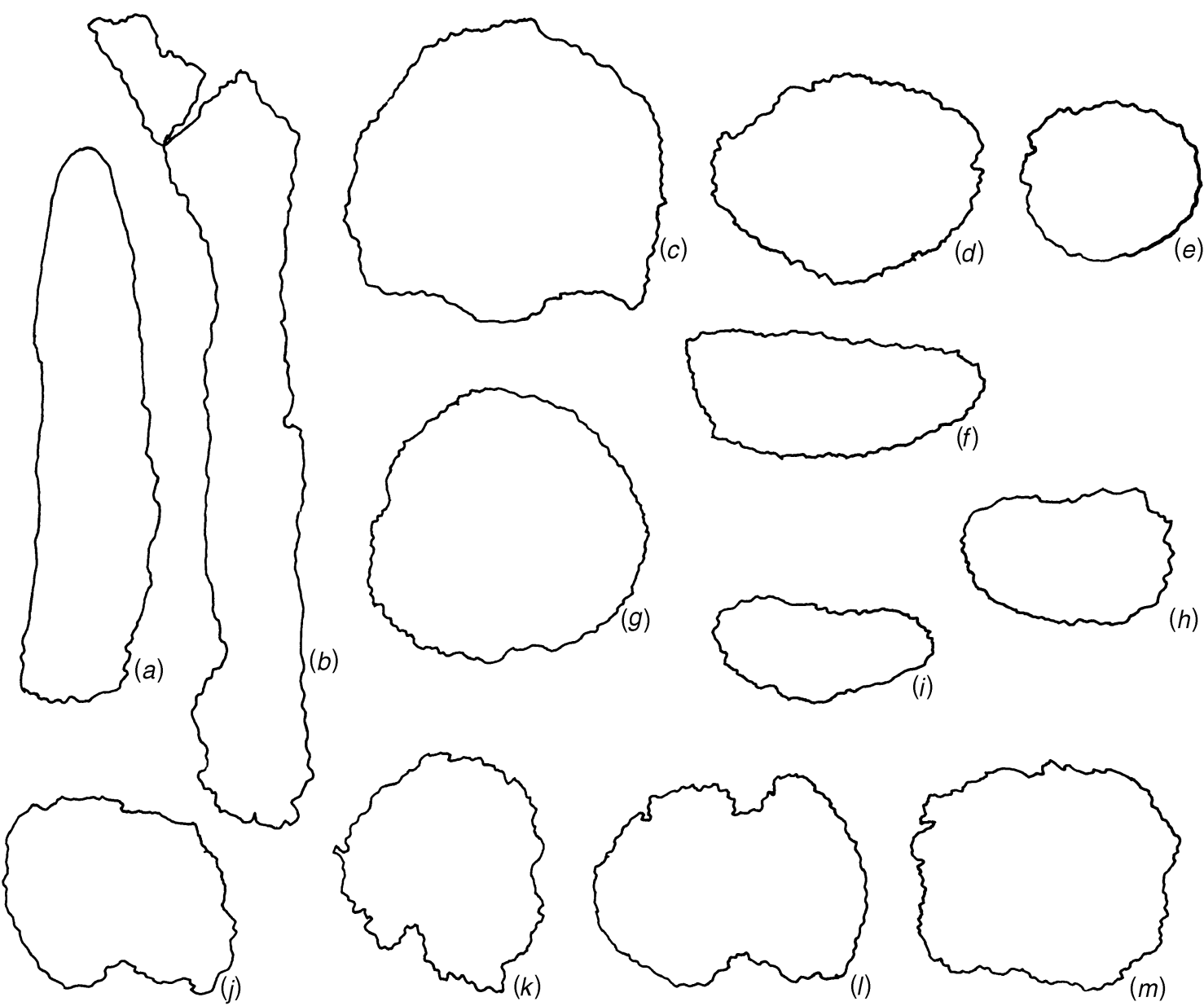

Figure 1. Outline of specimens. $(a, b)$ Type B, Ludford Lane (Pridoli). Magnification $\times 45$. (a) Elongate sporangium NMW96.11G.2. (b) Elongate sporangium NMW96.30G.3; (c-i) type A, Ludford Lane (Pridoli). Magnification $\times 45$.

(c) Discoidal sporangium NMW97.1G.1. (d) Discoidal spore mass NMW96.11G.1. (e) Discoidal spore mass NMW97.1G.2. $(f)$ Irregular spore mass NMW97.1G.3. $(g)$ Discoidal sporangium NMW96.30G.2. (h) Irregular spore mass NMW97.1G.4. (i) Irregular spore mass NMW97.1G.5; $(j)$ type D, North Brown Clee Hill (Lochkovian). Magnification $\times 40$. Discoidal sporangium NMW96.30G.6; $(k)$ type C, North Brown Glee Hill (Lochkovian). Magnification × 40. Discoidal spore mass NMW96.30G.5; $(l, m)$ type E, North Brown Clee Hill (Lochkovian). Magnification $\times 20$. $(l)$ Discoidal sporangium NMW96.30G.4. $(m)$ Discoidal sporangium NMW97.1G.6.

spore wall have been sectioned. They have bevelled edges where they penetrate the spore surface, are parallel sided, and they dramatically narrow, in a stepwise fashion, at the margin between the two wall layers. This stepped structure may relate to variation in the physical properties of the two wall layers. However, the origin of the holes is unknown and is the subject of a separate study. It is possible that they result from fungal or microarthropod attack, either while the plant was alive or post mortem. Spores in the discoidal sporangia are identical to those from the similarly shaped spore masses: in other words, bilayered with very little EEM (figure $3 f$ ).

\section{(iii) LM observations}

Group A spores were recovered from three of the spore masses (NMW97.1G.4, NMW97.1G.3, NMW96.11G.1) and both of the discoidal sporangia (NMW97.1G.1, NMW96.30G.2) (figure $3 i-k$ ). They are generally recovered dissociated, but rarely in dyads. The spores are 'clean' with no evidence of EEM. In many of the spores the characteristic holes are prominent (figure $3 j$ ). In all cases the spores are referable to L. divellomedia.

\section{(b) Group B (Ludford Lane)}

(See figures $1 a, b, 4$ and 5.)

\section{(i) SEM observations}

The two elongate sporangia (NMW96.11G.2 and NMW96.30G.3) are incomplete. Specimen NMW96. $11 \mathrm{G} .2$ is $1470 \mu \mathrm{m}$ long and broken towards one (?proximal) end, where it is $345 \mu \mathrm{m}$ in maximum width, and tapers very gradually to a semi-rounded termination at the other (?distal) end (figures $1 a$ and $4 b$ ). The sporangial cuticle is externally smooth with no noteworthy features. The inner surface of the cuticle is not exposed. Spores are visible at the broken (?proximal) end of the sporangium. Specimen NMW96.30G.3 is $1960 \mu \mathrm{m}$ long, but is broken off at both ends (figures $1 b$ and $4 a$ ). It is more or less parallel sided and $c a .280 \mu \mathrm{m}$ wide. The sporangial cuticle is externally smooth and featureless. Its inner surface is not exposed. Spores are visible where 


\section{Table 2. Characteristics of the five types of spore-wall ultrastructure identified}

(Regarding spore characters: (1) size refers to maximum spore diameter in microns (smallest(mean)largest) considering spores from all the specimens studied; (2) AD refers to abundance of intact dyads where C, common and R, rare; (3) EEM, extraexosporal material, where 0 , absent; 1 , type $1 ; 2$, type $2 ; 3$, type $3 ;(4) \mathrm{P}$ puckering in the region of the curvaturae where 0 , absent; 1, type 1; 2, type 2; (5) $\mathrm{H}$ characteristic holes where 0, absent; X, present; (6) CD refers to occurrence of characteristic degradation where 0 , absent; $\mathrm{X}$, present.)

spore characters

\begin{tabular}{|c|c|c|c|c|c|c|c|c|}
\hline \multicolumn{2}{|c|}{ type specimens } & spore-wall ultrastructure & (1) size & (2) $\mathrm{AD}$ & EEM & (4) $\mathrm{P}$ & (5) $\mathrm{H}$ & (6) $\mathrm{CD}$ \\
\hline A & $\begin{array}{l}\text { (1-7) Ludford Lane } \\
\text { discoidal sporangia-- } \\
\text { spore masses }\end{array}$ & $\begin{array}{l}\text { bilayered; outer layer homogeneous } \\
\text { and electron dense; inner layer } \\
\text { homogeneous and less electron dense; } \\
\text { layers of similar thickness }\end{array}$ & $17(26) 32$ & $\mathrm{R}$ & 0 & 0 & $\mathrm{X}$ & 0 \\
\hline B & $\begin{array}{l}(8,9) \text { Ludford Lane } \\
\text { elongate sporangia }\end{array}$ & $\begin{array}{l}\text { bilayered; outer layer homogeneous; } \\
\text { inner layer comprising laterally continuous } \\
\text { concentric lamellae lacking further } \\
\text { structure }\end{array}$ & $26(28) 32$ & $\mathrm{R}$ & 1 & 1 & 0 & 0 \\
\hline $\mathrm{C}$ & $\begin{array}{l}\text { (10) North Brown Glee } \\
\text { Hill discoidal spore } \\
\text { mass }\end{array}$ & $\begin{array}{l}\text { bilayered; outer layer thin and homo- } \\
\text { geneous; inner layer comprising laterally } \\
\text { discontinuous, overlapping and irregularly } \\
\text { spaced lamellae with tripartite structure }\end{array}$ & $34(36) 40$ & $\mathrm{R}$ & 2 & 2 & 0 & 0 \\
\hline $\mathrm{D}$ & $\begin{array}{l}\text { (11) North Brown Clee } \\
\text { Hill small discoidal } \\
\text { sporangium }\end{array}$ & homogeneous & $49(53) 59$ & C & 0 & 0 & 0 & 0 \\
\hline $\mathrm{E}$ & $\begin{array}{l}(12,13) \text { North Brown } \\
\text { Clee Hill large discoidal } \\
\text { sporangia }\end{array}$ & $\begin{array}{l}\text { bilayered; thin, outer homogeneous } \\
\text { layer and thick, grainy and homogeneous, } \\
\text { inner layer }\end{array}$ & $24(33) 42$ & $\mathrm{R}$ & 3 & 0 & 0 & $\mathrm{X}$ \\
\hline
\end{tabular}

the cuticle is missing. In both specimens the spores are remarkably constant in size and are dissociated (figure $4 d-l)$. They resemble $L$. divellomedia, except for the presence of abundant EEM (e.g. figure $4 f$ ) and puckering in the region of the curvatura (crassitude) (see, for example, figure $4 e$ ). In some spores it is evident that there is a discrete and continuous layer of material over the distal surface (see, for example, figure $4 e, f$ ). This layer has a weakly developed and patchy microgranulate ornament and is puckered where it terminates at the margin of the contact face. In addition, there are abundant small fragments of EEM scattered over this layer and it is probably this material that is responsible for the patchy microgranulate ornament.

\section{(ii) TEM observations}

Both elongate sporangia have spores with similar ultrastructure (figure 5). The walls are basically bilayered with a narrow homogeneous outer layer overlying a lamellate inner one. The lamellate layer incorporates at least 20 parallel superimposed lamellae, and in some spores is separated in places from the outer homogeneous part of the wall (see, for example, figure $5 g, h$ ). The lamellae are very prominent on the inner margin of the wall but may become difficult to discern towards the outer part and merge into the outer homogeneous layer. The lamellae are homogeneous, with no evidence of tripartite structure, and are $c a .40 \mathrm{~nm}$ thick. They appear to be continuous, perhaps extending around the entire spore. They are equidistant where compressed, but tend to separate and fold, particularly where the lamellate layer has pulled away from the outer layer. Globules of EEM are clearly discernible in the sections (see, for example, figures $5 b, c$ ).
The numerous globules are densely packed and frequently aggregated in places forming a nearly continuous layer (see, for example, figure $5 g$ ). They stain in a similar fashion to the outer homogeneous layer of the spore wall suggesting that both may have a similar origin. Both the globules of EEM and the outer exospore layer persist following oxidation. It is unclear whether the outer homogeneous layer and the layer of densely packed globules covering it extend over the contact area. It is possible that they do not extend over the contact area and comprise the discrete and continuous layer of material over the distal surface which is evident from SEM analysis (see previous paragraph).

\section{(iii) LM observations}

Spores were recovered from both of the elongate sporangia (figure $4 c$ ). They are generally dissociated, but only occasionally in dyads. In some of the spores there is evidence of fine folds on the proximal face. The crassitudes are relatively prominent and, although they appear slightly corrugated, the puckering is not conspicuous. In some spores fragments of EEM remain attached to the spores. Despite the prominent, slightly corrugated, crassitude and fragments of EEM these spores and would be referred to $L$. divellomedia sensu lato if found dispersed.

\section{(c) Group C (North Brozn Clee Hill)}

(Figures $1 k, 6$ and 7.)

\section{(i) SEM observations}

Spore mass NMW96.30G.5 is discoidal and $740 \mu \mathrm{m}$ in maximum diameter (figures $1 k$ and $6 a$ ). The spores are uniform in size and generally occur dissociated, although 

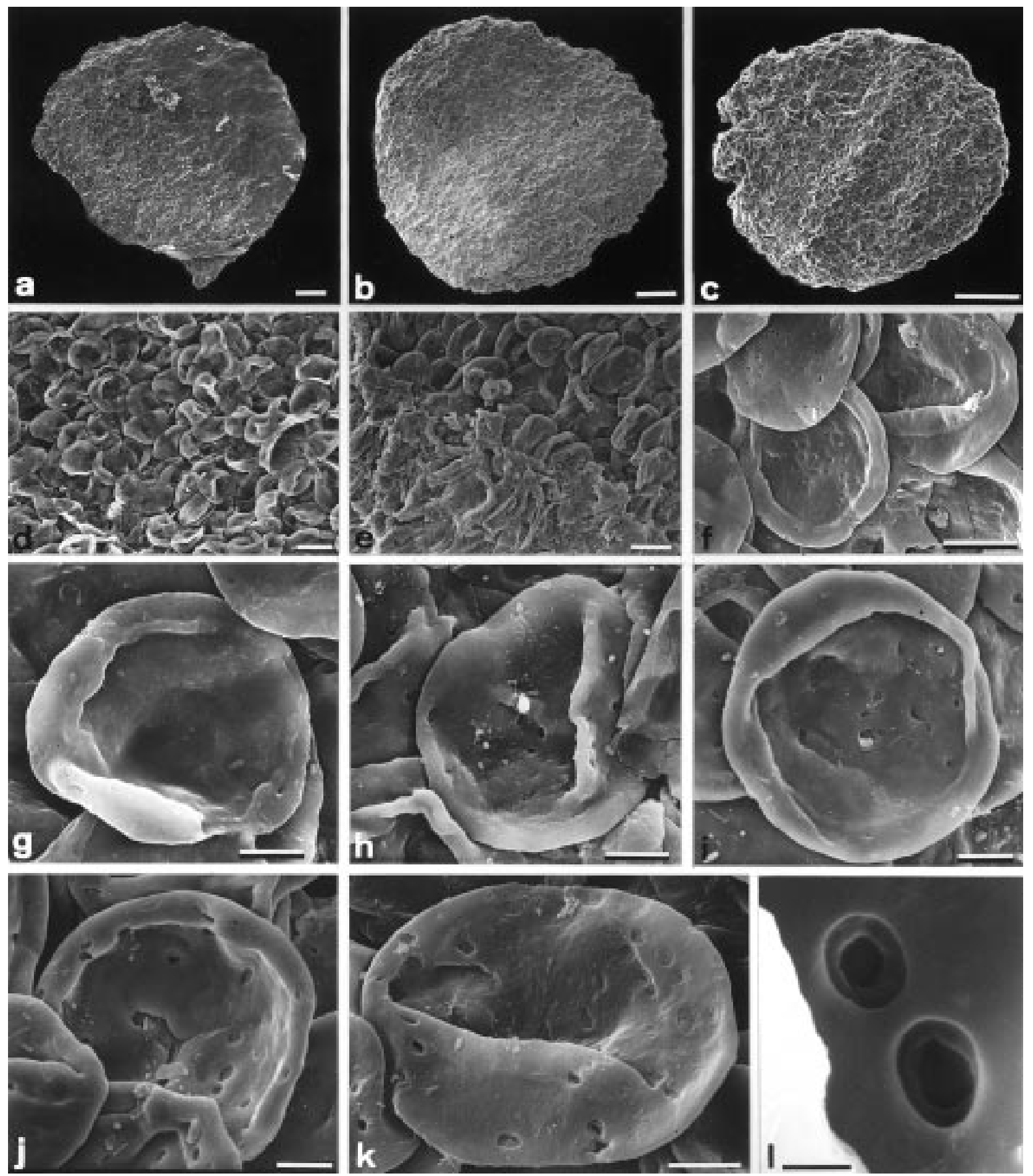

Figure 2. SEMs of in situ Laevolancis divellomedia type A. All specimens from Ludford Lane, Welsh Borderland (Pridoli). ( $a, g$ ) Specimen NMW97.1G.1. (a) Discoidal sporangium. Scale bar, $100 \mu \mathrm{m}$. (g) Close-up of in situ spore. Scale bar, $5 \mu \mathrm{m}$. $(b, e, f)$ Specimen NMW96.30G.2. (b) Discoidal sporangium. Scale bar, $100 \mu \mathrm{m}$. (e) In situ spores from the discoidal sporangium. Note the sporangium wall in the lower part of the photograph. Scale bar, $20 \mu \mathrm{m}$. $(f)$ Close-up of in situ spores. Note the characteristic holes. Scale bar, $10 \mu \mathrm{m}$. $(c, h)$ Specimen NMW97.1G.2. (c) Discoidal spore mass. Scale bar, $100 \mu \mathrm{m}$. $(h)$ Close-up of in situ spore. Note the characteristic holes. Scale bar, $5 \mu \mathrm{m}$. $(d, l)$ Specimen NMW97.1G.4. (d) In situ spores from a discoidal spore mass. Scale bar, $20 \mu \mathrm{m}$. (l) Close-up of one of the characteristic holes. Note the constriction within the hole. Scale bar, $1 \mu \mathrm{m}$. $(i, k)$ Specimen NMW97.1G.3. (i) Close-up of in situ spore. Note the characteristic holes. Scale bar, $5 \mu \mathrm{m}$. (k) Close-up of an oxidized in situ spore. Note the characteristic holes. Scale bar, $5 \mu \mathrm{m}$. ( $j$ ) Specimen NMW96.11G.1. Close-up of in situ spore. Note the characteristic holes. Scale bar, $5 \mu \mathrm{m}$.

rare dyads are present. They are similar to L. divellomedia, except for the presence of a slight puckering on the inner margin of the curvatura delimiting the contact area (see figure $6 f$ ). Scattered fragments of EEM are discernible on both the proximal and distal surfaces of the spores. The fragments are irregular in shape and generally $1-5 \mu \mathrm{m}$ in maximum diameter. However, some fragments occur in sheets up to $13 \mu \mathrm{m}$ in maximum diameter (see, for 

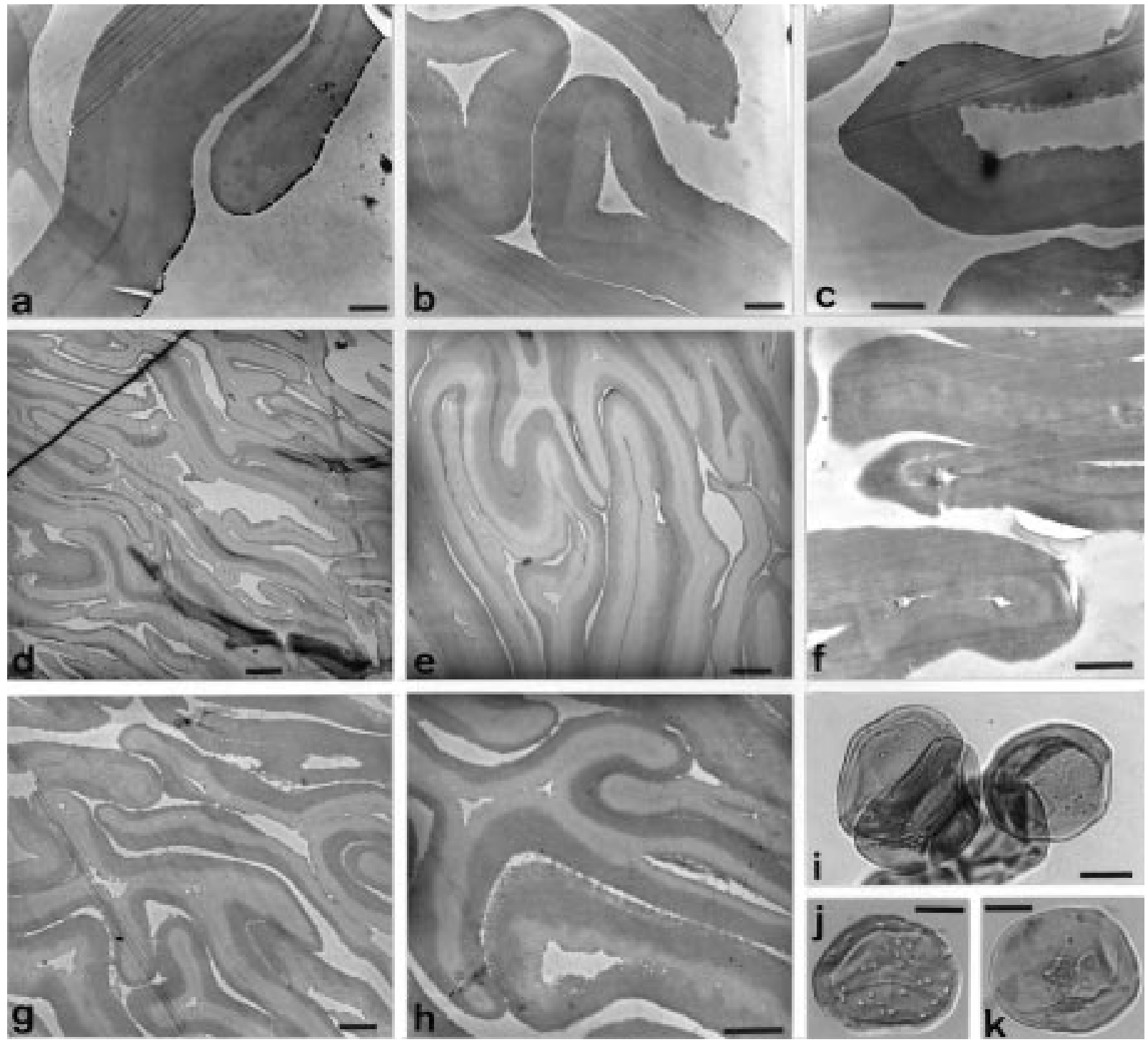

Figure 3. TEMs $(a-h)$ and LMs $(i-k)$ of in situ Laevolancis divellomedia type A. All specimens from Ludford Lane, Welsh Borderland (Pridoli). ( $a-c)$ Specimen NMW96.11G.1. All unoxidized and unstained. Scale bar, $1 \mu \mathrm{m} .(d, e, g, h)$ Specimen NMW97.1G.2. (d) Unoxidized and stained. Scale bar, $2 \mu \mathrm{m}$. (e) Unoxidized and stained. Scale bar, $1 \mu \mathrm{m}$. ( $g, h)$ Oxidized and stained. Scale bar, $1 \mu \mathrm{m} .(f)$ Specimen NMW96.30G.2. Unoxidized and unstained. Scale bar, $1 \mu \mathrm{m}$. $(i-k)$ Specimen NMW96.11G.1. (i) LM of spores physically isolated from the specimen. Oxidized. Scale bar, $10 \mu \mathrm{m}$. $(j) \mathrm{LM}$ of single spore physically isolated from the specimen. Oxidized. Note the characteristic holes. Scale bar, $10 \mu \mathrm{m}$. $(k)$ LM of single spore physically isolated from the specimen. Oxidized. Scale bar, $10 \mu \mathrm{m}$.

example, figure $6 e$ ). Bacteria are evident on the surface of the specimen (see figure 6e). This is almost certainly modern contamination occurring following isolation, but before coating.

\section{(ii) TEM observations}

The spores in specimen (NMW96.30G.5) have a highly distinctive ultrastructure (figure 7). The walls are essentially bilayered, both layers extending over the proximal and distal surfaces. The outer layer is $20-40 \%$ (usually in the region of $30 \%$ ) of the total wall thickness and is homogeneous. The inner part of this layer is compact, but towards the outside it becomes less compact and appears to comprise globules compressed together. At the surface of the spore discrete fragments of EEM, comprising material ultrastructurally identical to that in the outer layer, are discernible (for example, the arrows in figure $7 e, h$ ).
Both the fragments of extra-exosporal material and the outer exospore layer persist following oxidation. The inner layer is lamellate. The lamellae appear identical to the white-line-centred lamellae that have been widely reported among extant plants and certain algae (see, for example, Blackmore \& Barnes 1987). A central electronlucent layer, of constant dimensions and less than $8 \mathrm{~nm}$ in thickness, is bounded on either side by electron dense material. The numerous superimposed white lines (at least $30)$ are not equidistant, the distance between them usually varying from between $8-25 \mathrm{~nm}$, but occasionally up to $45 \mathrm{~nm}$. Thus, if we assume the white-line-centred lamellae have a tripartite structure, they are $c a .20-55 \mathrm{~nm}$ wide, but more usually $c a .20-35 \mathrm{~nm}$ in width. The lamellae are clearly not continuous around the spore but occur as plates that are not laterally extensive. They are of irregular width, non-parallel, and overlapping, suggesting 

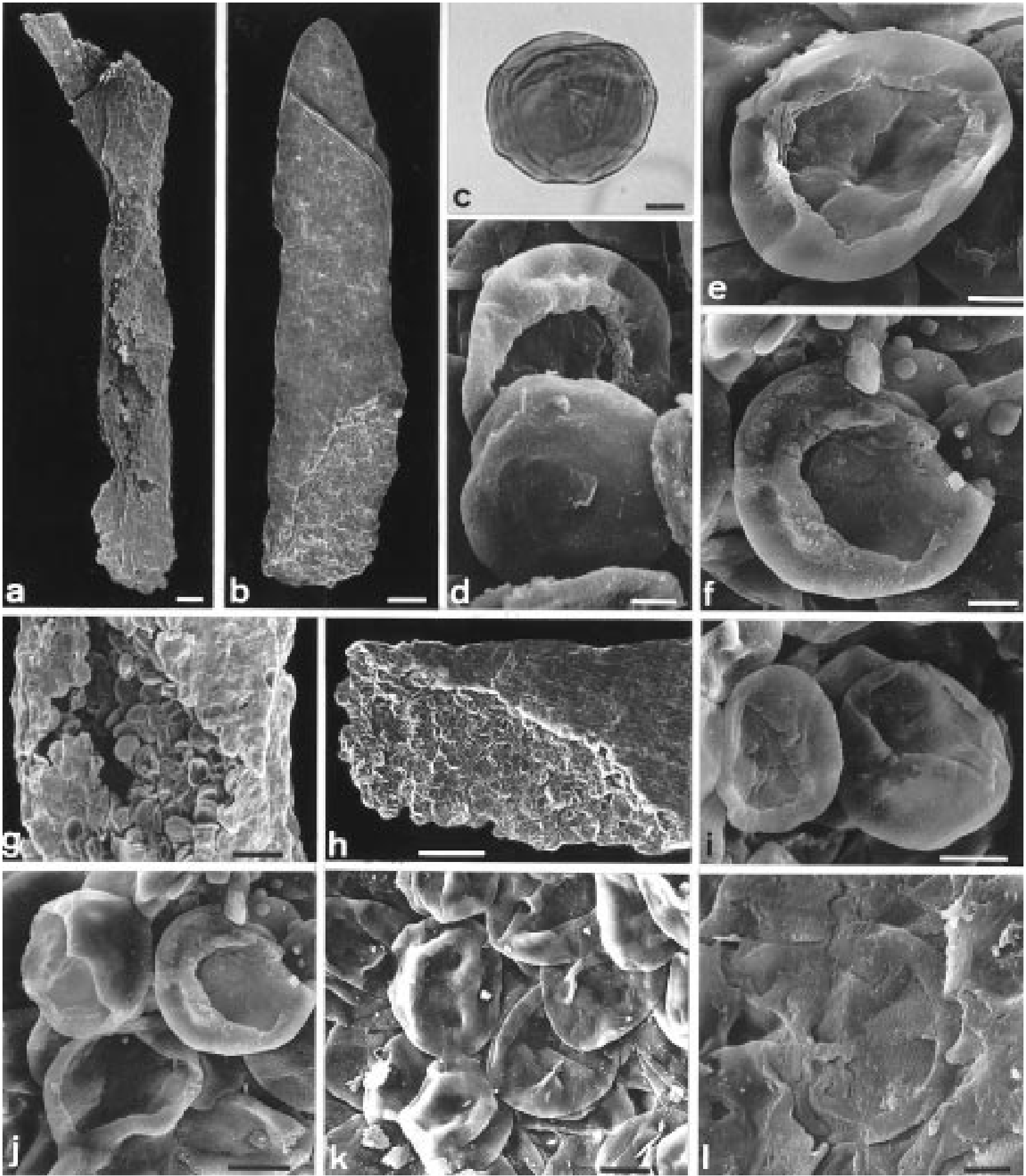

Figure 4. SEMs and LM $(c)$ of in situ Laevolancis divellomedia sensu lato type B. All specimens from Ludford Lane, Welsh Borderland (Pridoli). $(a, c-g, i-j)$ Specimen NMW96.30G.3. (a) Elongate sporangium. Scale bar, $100 \mu \mathrm{m}$. (c) LM of single dyad physically isolated from the specimen. Oxidized. Scale bar, $5 \mu \mathrm{m}$. $(d)$ Close-up of in situ spores. Scale bar, $5 \mu \mathrm{m}$. (e) Close-up of in situ spore. Oxidized. Note the folding surrounding the contact area. Scale bar, $5 \mu \mathrm{m}$. $(f)$ Close-up of in situ spore. Oxidized. Note the outer layer over the distal, but not the proximal, surface. Scale bar, $5 \mu \mathrm{m}$. (g) Part of sporangium split revealing in situ spores. Scale bar, $50 \mu \mathrm{m}$. (i) Close-up of in situ spores. Oxidized. Scale bar, $10 \mu \mathrm{m}$. ( $j$ ) Close-up of in situ spores. Oxidized. Scale bar, $10 \mu \mathrm{m}$. $(b, h, k, l)$ Specimen NMW96.11G.2. (b) Elongate sporangium. Scale bar, $100 \mu \mathrm{m}$. $(h)$ Part of sporangium with cuticle removed revealing in situ spores. Scale bar, $100 \mu \mathrm{m}$. (k) Close-up of in situ spores. Scale bar, $10 \mu \mathrm{m}$. (l) Close-up of in situ spores. Oxidized. Note the abundant extra-exosporal material. Scale bar, $5 \mu \mathrm{m}$.

that either the lamellae have been compressed in an irregular manner or sporopollenin deposition on the lamellae was irregular. As is often the case in extant plants, there is no obvious junction between the electron-dense material separating the white lines, so the tripartite structure is not apparent.

\section{(iii) LM observations}

We failed to recover spores sufficiently well preserved for LM analysis from specimen NMW96.30G.5.

\section{(d) Group D (North Brown Clee Hill)}

(See figures $1 j$ and 8 .) 

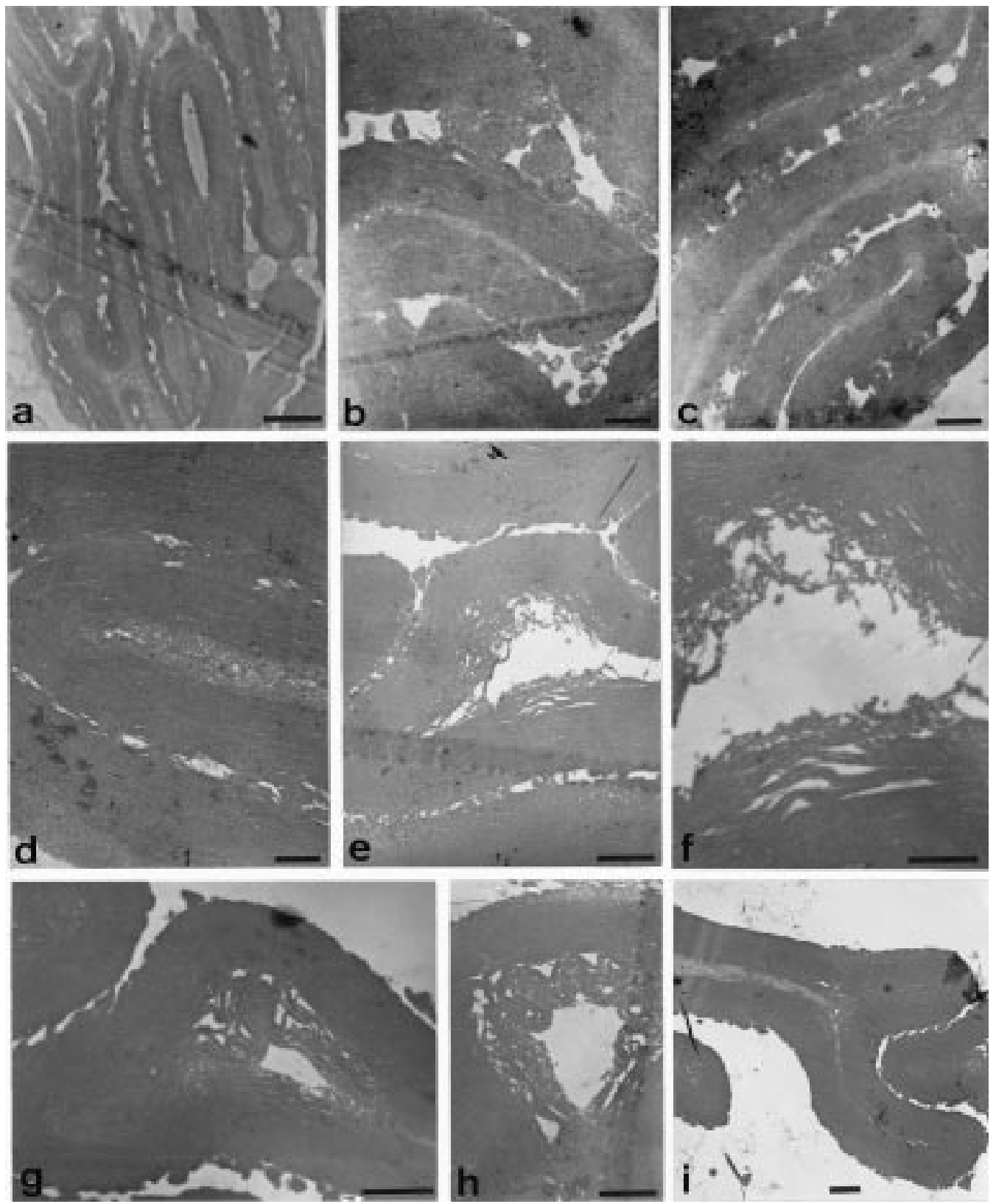

Figure 5. TEMs of in situ Laevolancis divellomedia sensu lato type B. All specimens from Ludford Lane, Welsh Borderland (Pridoli). $(a-c)$ Specimen NMW96.11G.2. (a) Oxidized and stained. Scale bar, $1 \mu \mathrm{m}$. (b) Oxidized and stained. Note the abundant extraexosporal material. Scale bar, $0.5 \mu \mathrm{m}$. (c) Oxidized and stained. Note the abundant extra-exosporal material. Scale bar, $0.5 \mu \mathrm{m}$. $(d-i)$ Specimen NMW96.30G.3. (d) Oxidized and stained. Scale bar, $0.5 \mu \mathrm{m}$. (e) Oxidized and stained. Note the lamellae. Scale bar, $1 \mu \mathrm{m}$. $(f)$ Oxidized and stained. Note the lamellae. Scale bar, $0.5 \mu \mathrm{m}$. $(g)$ Oxidized and stained. Note the inner lamellate layer separating from the outer layer. Scale bar, $1 \mu \mathrm{m}$. $(h)$ Oxidized and stained. Note the inner lamellate layer separating from the outer layer. Scale bar, $1 \mu \mathrm{m}$. (i) Oxidized and stained. Scale bar, $1 \mu \mathrm{m}$.

\section{(i) SEM observations}

The discoidal sporangium, NMW96.30G.6, contains typical laevigate hilate cryptospores (referable to L. divellomedia sensu lato) and measures $780 \mu \mathrm{m}$ in maximum diameter (figures $1 j$ and $8 a-f$ ). The external surface of the presumed sporangial cuticle is laevigate and featureless and the internal surface cannot be seen. Little or no EEM is present on or between the spores. The spores frequently occur in dyads although dissociated spores are also present.

\section{(ii) TEM observations}

The wall of the spores in specimen NMW96.30G.6 generally appears to consist of a single homogeneous layer (figure $8 g-k$ ). However, in places the exospore has a spongy appearance, primarily at the equator and, away from the latter, on the inner portion of the spore wall. This may represent a variation in wall composition or a taphonomic or preparational artefact. Whatever the case, the ultrastructure of these spore walls is clearly different from that in the spores from the other discoidal sporangia from North Brown Clee Hill (NMW96.30G.4 and NMW97.1G.6) (see next section).

\section{(iii) LM observations}

Many of the spores recovered from NMW96.30G.6 remained in dyads (figure $8 l, m$ ) although some 

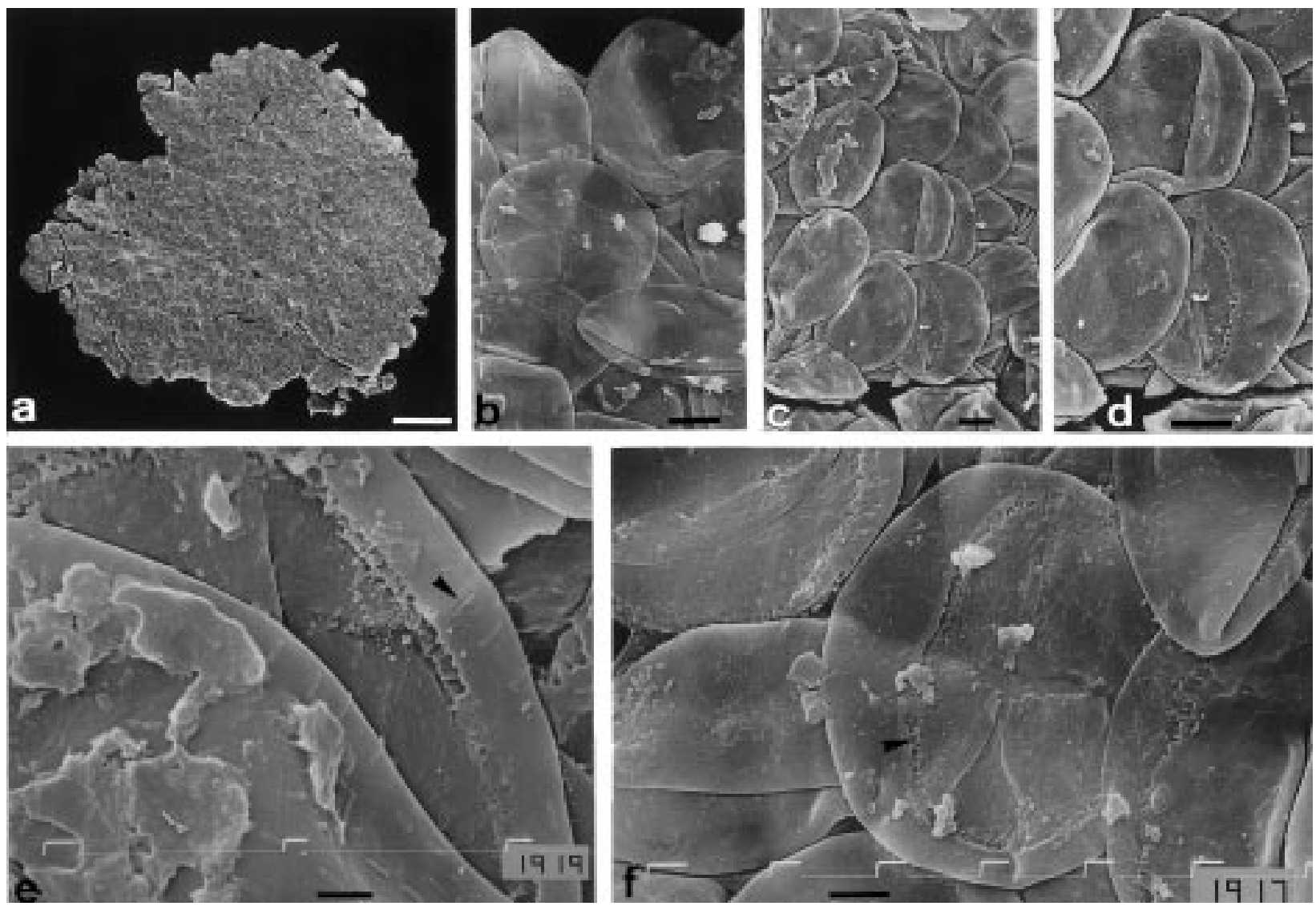

Figure 6. SEMs of in situ Laevolancis divellomedia sensu lato type C. Specimen (NMW96.30G.5) from North Brown Clee Hill, Welsh Borderland (Lochkovian). (a) Discoidal spore mass. Scale bar, $100 \mu \mathrm{m} .(b-d)$ Close-up of in situ spores. Scale bar, $10 \mu \mathrm{m}$.

(e) Close-up of in situ spores. Note the sheet of extra-exosporal material and the recent bacterial contamination (arrow). Scale bar, $2 \mu \mathrm{m}$. $(f)$ Close-up of in situ spores. Note the puckering associated with the margin of the contact area (arrow). Scale bar, $5 \mu \mathrm{m}$.

dissociated spores were also recovered. The spores are clean with no evidence for attached EEM. The dyads can be accommodated in Dyadospora murusdensa and the dissociated monads in L. divellomedia sensu lato.

\section{(e) Group E (North Brown Clee Hill)}

(See figures $1 l, m$ and 9 .)

\section{(i) SEM observations}

Specimens NMW96.30G.4 and NMW97.1G.6 are also discoidal sporangia containing laevigate hilate cryptospores referable to $L$. divellomedia sensu lato (figures $1 l, m$ and $9 a, b, f-k)$. They are larger than NMW96.30G.6 measuring $1400 \mu \mathrm{m}$ and $1640 \mu \mathrm{m}$ in maximum diameter, respectively. Again the external surface of the presumed sporangial cuticle is laevigate and featureless, and the internal surface cannot be seen. Discrete, sub-spherical, globules of EEM are present between spores in both specimens. They measure $c a$. $150-1800 \mathrm{~nm}$ in maximum diameter. In both specimens some of the spores appear degraded (see, for example, figure $9 g$ ). The spores differ from those in NMW96.30G.6 because they are predominantly dissociated and are smaller (see table 1).

\section{(ii) TEM observations}

The two larger discoidal sporangia from North Brown Clee Hill (NMW96.30G.4 and NMW97.1G.6) have identical spore wall ultrastructure (figure $9 l-n$ ). They are bilayered and both layers are homogeneous. The outer layer comprises $10-15 \%$ of the wall thickness. It is divided from the inner layer by a faint, dark line (figure $9 \mathrm{~m}$ ). The inner layer is slightly more electron dense than the outer and is 'grainy' in appearance. The sections reveal no evidence for the degradation seen in SEM studies of some spores. The globules of EEM are clearly visible, the smaller ones being spherical whereas the larger ones are often flattened to varying degrees (see figure $9 m, n$ ). The globules are of similar electron density to the outer layer of the wall and are bounded by a narrow dark line similar to that separating the inner and outer exospore layers. Both the globules of EEM and the outer exospore layer persist following oxidation.

\section{(iii) LM observations}

Spores were recovered from both specimens (figure $9 c-e)$. They are predominantly dissociated, although rare dyads were also recovered, and are referable to L. divellomedia sensu lato. There is no evidence for globules of EEM. It is possible that these become detached from the spores when they were physically separated. In some of the spores the wall appears patchy which is possibly a manifestation of the characteristic degradation. 

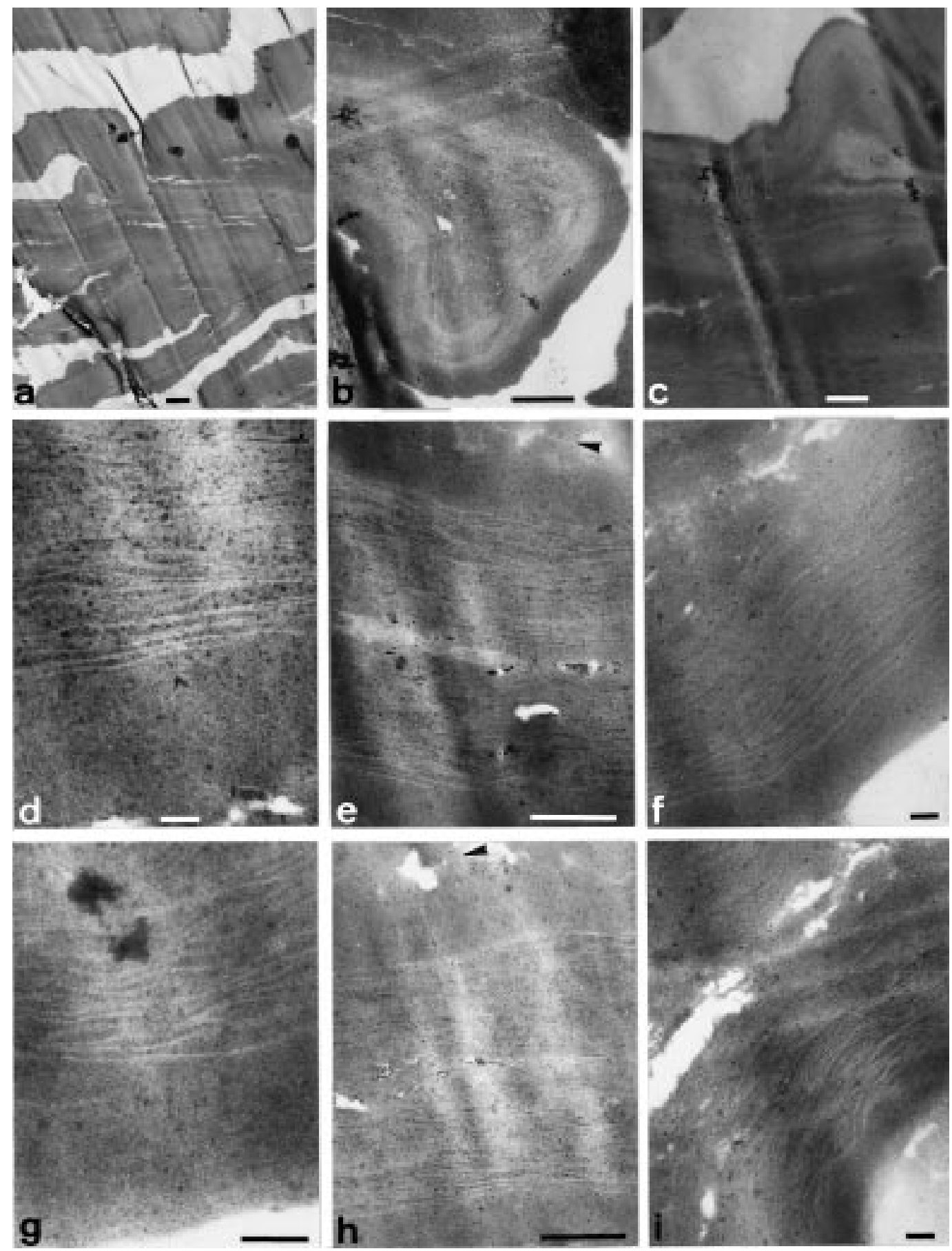

Figure 7. TEMs of in situ Laevolancis divellomedia sensu lato type G. Specimen (NMW96.30G.5) from North Brown Clee Hill, Welsh Borderland (Lochkovian). (a) Unoxidized and stained. Scale bar, $1 \mu \mathrm{m}$. $(b, c)$ Unoxidized and stained. Scale bar, $0.5 \mu \mathrm{m}$.

(d) Unoxidized and stained. Note the white-line-centred lamellae. Scale bar, $0.1 \mu \mathrm{m}$. (e) Unoxidized and stained. Note the white-line-centred lamellae. Scale bar, $0.5 \mu \mathrm{m}$. $(f, g)$ Unoxidized and stained. Note the white-line-centred lamellae. Scale bar, $0.1 \mu \mathrm{m} .(h)$ Unoxidized and stained. Note the white-line-centred lamellae. Scale bar, $0.5 \mu \mathrm{m}$. (i) Unoxidized and stained. Note the white-line-centred lamellae. Scale bar, $0.1 \mu \mathrm{m}$.

\section{SPORE IDENTIFICATION}

In most of the specimens described here, the in situ spores can be accommodated in the 'concept' of L. divellomedia sensu lato, as outlined in the diagnosis and description (Burgess \& Richardson 1991) formulated following LM and SEM studies of dispersed spores. The exceptions are spores from the group B elongate sporangia (NMW96.11G.2 and NMW96.30G.3) and the group C discoidal spore mass (NMW96.30G.5). The former possess a discrete layer with a sporadic microgranulate ornament, which is only present outside the contact area, and is slightly puckered in the region of the curvaturae. The latter is distinctly puckered in the region of the curvaturae.

In the case of the spores in the group B specimens, it is unclear if the outer layer would be lost (sloughed off) before dispersal or would remain on the dispersed spores. 

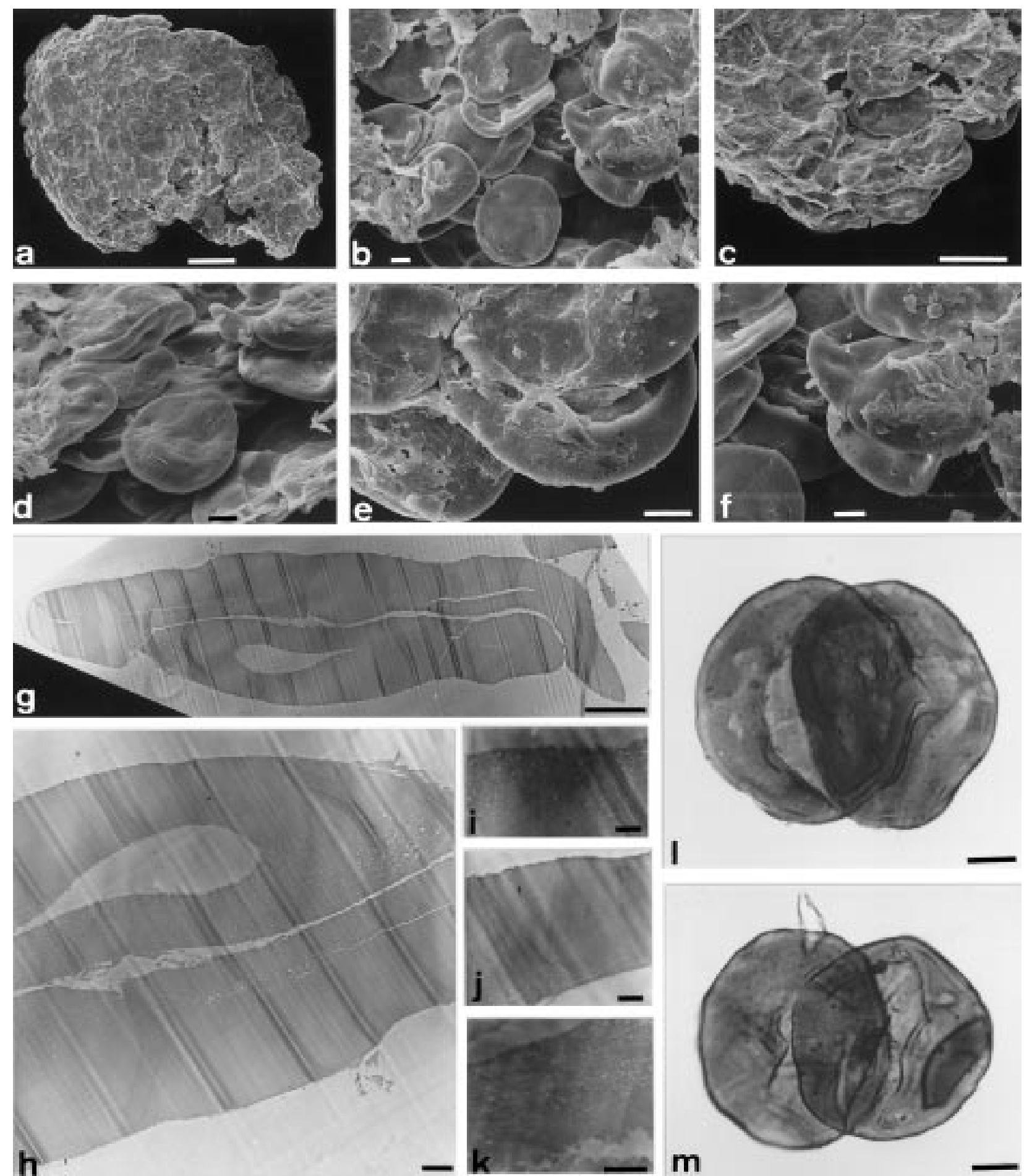

Figure 8. SEMs $(a-f)$, TEMs $(g-k)$ and LMs $(l-m)$ of in situ Laevolancis divellomedia sensu lato type D. Specimen (NMW96.30G.6 from North Brown Clee Hill, Welsh Borderland (Lochkovian). (a) SEM of discoidal sporangium. Scale bar, $100 \mu \mathrm{m}$. (b) SEM close-up of in situ spores. Scale bar, $10 \mu \mathrm{m}$. (c) SEM close-up of in situ spores. Note sporangial wall. Scale bar, $50 \mu \mathrm{m}$. $(d)$ SEM close-up of in situ spores. Note the presence of dyads. Scale bar, $10 \mu \mathrm{m}$. (e) SEM close-up of in situ spores. Scale bar, $10 \mu \mathrm{m}$. $(f)$ SEM close-up of in situ spores. Scale bar, $10 \mu \mathrm{m}$. $(g)$ TEM of dyad. Unoxidized and stained. Scale bar, $5 \mu \mathrm{m}$. $(h)$ TEM of dyad. Oxidized and stained. Scale bar, $1 \mu \mathrm{m}$. $(i, j)$ TEMs of single wall. Oxidized and stained. Scale bar, $0.5 \mu \mathrm{m}$. $(k)$ TEM of single wall. Oxidized and unstained. Scale bar, $0.5 \mu \mathrm{m} .(l, m) \mathrm{LM}$ of single dyad physically isolated from the specimen. Oxidized. Scale bar, $10 \mu \mathrm{m}$.

If preserved, it is likely that the microgranulate ornament, which is very fine and probably at the limits of optical resolution, would be either indiscernible or dismissed as a preservational artefact when examined using LM. The puckering would be lost if this layer sloughed off but is anyway rather subtle and probably would not be discernible when examined using LM. LM examination of physically isolated spores demonstrates that fragments of EEM clearly survive oxidation and are discernible, but the presence of a distinct outer layer outside of the contact area cannot be ascertained, although this presumably also survives oxidation. 

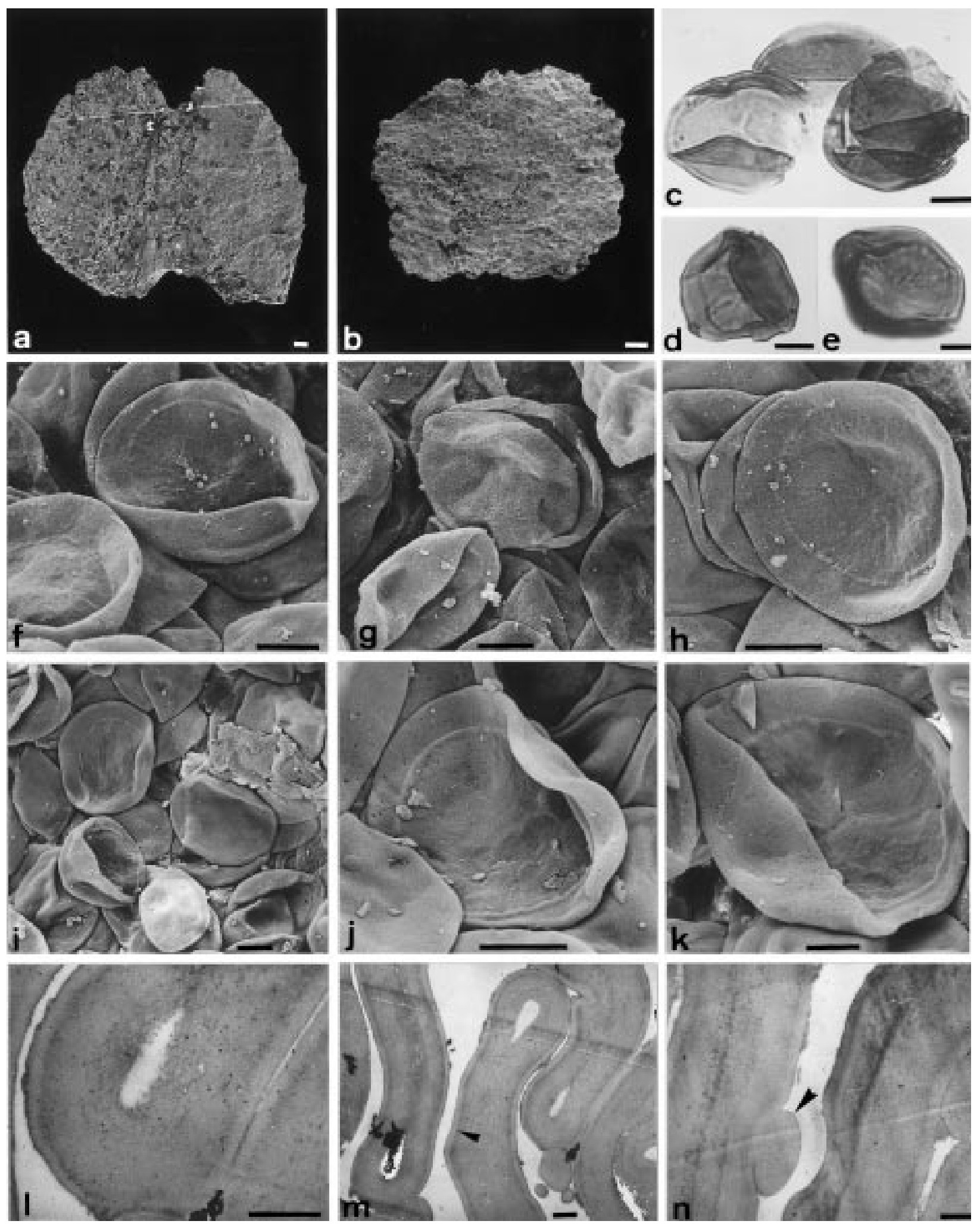

Figure 9. LMs $(c-e)$, SEMs $(a, b, f-k)$ and TEMs $(l-n)$ of in situ Laevolancis divellomedia sensu lato type E. Both specimens from Lochkovian deposits from North Brown Glee Hill, Shropshire, UK $(a, c-d, f-h, l-n)$ specimen NMW96.30G.4. (a) SEM of discoidal sporangium. Scale bar, $100 \mu \mathrm{m}$. (c) LM of spores physically isolated from the specimen. Oxidized. Scale bar, $10 \mu \mathrm{m}$. (d) LM of single spore physically isolated from the specimen. Oxidized. Scale bar, $10 \mu \mathrm{m}$. $(f)$ SEM of close-up of in situ spores. Scale bar, $10 \mu \mathrm{m}$. $(\mathrm{g}) \mathrm{SEM}$ of close-up of in situ spores. Note characteristic degradation. Scale bar, $10 \mu \mathrm{m}$. $(h)$ SEM of close-up of in situ spores. Scale bar, $10 \mu \mathrm{m}$. ( $l$ ) TEM. Unoxidized and stained. Scale bar, $0.5 \mu \mathrm{m}$. $(\mathrm{m})$ TEM. Unoxidized and stained. Note extra-exosporal material and the dark line separating exospore layers (arrowed). Scale bar, $0.5 \mu \mathrm{m}$. (n) TEM. Oxidized and stained. Note EEM (arrowed). Scale bar, $0.5 \mu \mathrm{m}$. $(b, e, i-k)$ Specimen NMW97.1G.6. (b) SEM of discoidal sporangium. Scale bar, $100 \mu \mathrm{m}$. (e) LM of single spore physically isolated from the specimen. Oxidized. Scale bar, $10 \mu \mathrm{m}$. ( $i, j$ ) SEMs of close-up of $i n$ situ spores. Scale bar, $10 \mu \mathrm{m}$. (k) SEM of close-up of in situ spores. Scale bar, $5 \mu \mathrm{m}$. 
Furthermore, although the crassitude appears prominent the puckering is not conspicuous.

The puckering in the group $\mathrm{C}$ specimen is fairly prominent and would almost certainly be discernible when examined using LM, thus necessitating questionable designation to $L$. divellomedia. These spores might even belong with the recently described Artemopyra? scalariformis Richardson, 1996b (Lochkovian, Welsh Borderland) which has a similar puckered border on the inner margin of the curvatura. However, spores were not recovered for LM examination from this specimen.

\section{COMMENTS ON EXTRA-EXOSPORAL MATERIAL}

EEM is clearly present in specimens assigned to groups $\mathrm{B}, \mathrm{C}$ and $\mathrm{E}$, but in each case differs in form (see descriptions here), and its exact nature is unclear. EEM has previously been reported associated with the spores of Cooksonia pertoni, where it occurs as a continuous peripheral layer and, in some cases, as an intersporal 'matrix' (Rogerson et al. 1993; Edwards et al. 1995a), and Resilitheca salopensis, where it occurs as discrete particles (Edwards et al. 1995c). These authors provided detailed discussion of its form, origin and possible homologies, but they were uncertain of its exact relationship with similar material in extant plants, although they were of the opinion that it in all cases it derived from a tapetum. Edwards et al. (1995a) suggested that the peripheral layer associated with C. pertoni does not represent perispore sensu stricto because in extant plants perispore is highly ordered, sometimes with taxon specific surface ornament, and seems to comprise a far more discrete layer. They also suggested that the intersporal 'matrix', which differs from the peripheral layer because it is more granular and less electron dense, is either the remains of a periplasmodial tapetum or, more likely, remnants of locular fluid. They suggested that the latter may have fossilization potential because of its 'colloidal or viscous nature, itself possibly owing to the presence of more recalcitrant molecules as precursors of sporopollenin'. Edwards et al. (1995c) suggested that the EEM of $R$. salopensis might be comparable to the globules of pteridophytes and the Ubisch bodies of angiosperms.

Group B spores have a distinct outer layer which is present only outside the contact area. It is unclear if this layer corresponds to the homogeneous outer exospore layer and/or the layer of EEM that coats it. Whatever the case, it seems likely that the outer layer was deposited around the dyad before separation. On separation of the dyad this layer would have ruptured at the junction between the spores producing the puckered effect that surrounds the contact area. Similarities in ultrastructural characteristics suggest that the material comprising both the homogeneous outer exospore layer and the EEM derives from the same source: this was presumably tapetal although this is unproven in the absence of direct observations of wall synthesis. However, it is also possible that the outer exospore layer does not comprise a discrete tapetally derived layer, but is essentially part of the inner lamellate layer where the lamellae have been obscured either owing to compression and/or when further sporopollenin was accreted.

Group C spores have a narrow, homogeneous, outer exospore layer that surrounds the entire spore, and are associated with fragments of EEM that comprise ultrastructurally similar material. Again there is puckering at the margin of the contact face. The outer exospore layer is less compacted towards the outside where individual globules are apparent. It is possible that this layer formed by the addition and gradual homogenization of such globules. Towards the outer part of the layer the globules are less compacted and therefore discernible. The ultrastructurally identical fragments of EEM probably derive from the same source and represent a later phase of deposition. Again a tapetal source for both seems likely, but cannot be proven.

Group E spores have a narrow, homogeneous, outer exospore layer, which is continuous around the spores, and is associated with discrete, sub-spherical, globules of EEM. Both are ultrastructurally identical such that a tapetal origin for both is considered.

In all three groups, the EEM is ultrastructurally identical to a narrow, homogeneous, outer exospore layer suggesting that both had the same, probably tapetal, source. In group B it is possible that the main phase of deposition occurred before dyad separation, but the contact areas were isolated, resulting in an outer layer that covers only the distal surface of the spores. However, in groups $\mathrm{C}$ and $\mathrm{E}$ the outer exospore layer surrounds the entire spore suggesting that either deposition occurred before dyad separation, but the contact areas were not isolated, or after dyad separation. Material remaining after completion of the outer exosporal layers probably condensed to form the small fragments of EEM that are attached to the spores. Such evidence points to the EEM being residues of the developmental process rather than representing a perispore in the strict sense (i.e. as a discrete layer in extant spores - see Lugardon 1990). However, they both represent final phases in sporopollenin deposition.

\section{AFFINITIES}

In an attempt to understand the affinities of the described specimens, we survey the distribution of dyadproducing plants and compare spore ultrastructure and other characters preserved in our specimens with those of fossil and extant land plants.

\section{(a) Plants with in situ dyads}

Dyads occur only rarely in extant non-angiosperm plants where they form as a result of meiotic irregularity. In the absence of a modern counterpart the mechanics of dyad production in early land plants, and its adaptive significance, if any, remain uncertain. Possible explanations have been discussed by Fanning et al. (1991), Gray (1993), Hemsley (1994) and Richardson (1996b,c). Most authors believe the dyads formed via normal meiosis producing haploid spores. If this is the case, it seems likely that meiosis was successive, where the products of the first meiotic division were separated by a special cell wall, with sporopollenin deposition occurring after the second division.

Laevigate and distally ornamented hilate cryptospores were reported from latest Silurian and earliest Devonian rhyniophytoids by Fanning et al. (1991) and Edwards et al. (1994), respectively. Both specimens are rather 
Table 3. Details of spore-wall ultrastructure in Ordovician-Early Devonian spores

\begin{tabular}{|c|c|c|c|}
\hline taxon-morphotype & occurrence-age & exospore ultrastructure & reference \\
\hline $\begin{array}{l}\text { Ambitisporites sp. } \\
\text { (crassitate trilete spore) }\end{array}$ & $\begin{array}{l}\text { in situ in Cooksonia pertoni } \\
\text { (Pridoli) }\end{array}$ & bilayered with peripheral coalified layer & Rogerson et al. (1993) \\
\hline $\begin{array}{l}\text { Synorisporites verrucatus } \\
\quad \text { (crassitate trilete spore) }\end{array}$ & $\begin{array}{l}\text { in situ in Cooksonia pertoni } \\
\text { (Lochkovian) }\end{array}$ & $\begin{array}{l}\text { bilayered with peripheral coalified layer. } \\
\text { Layering contours sculpture }\end{array}$ & Edwards et al. (1995a) \\
\hline $\begin{array}{l}\text { Streelispora newportensis } \\
\quad \text { (crassitate trilete spore) }\end{array}$ & $\begin{array}{l}\text { in situ in Cooksonia pertoni } \\
\text { (Lochkovian) }\end{array}$ & $\begin{array}{l}\text { bilayered with peripheral coalified layer. } \\
\text { Layering does not contour sculpture }\end{array}$ & Edwards et al. $(1995 a)$ \\
\hline $\begin{array}{l}\text { Aneurospora } \text { sp. } \\
\quad \text { (crassitate trilete spore) }\end{array}$ & $\begin{array}{l}\text { in situ in Cooksonia pertoni } \\
\text { (Pridoli) }\end{array}$ & $\begin{array}{l}\text { bilayered with peripheral coalified layer. } \\
\text { Layering does not contour sculpture }\end{array}$ & Edwards et al. $(1995 a)$ \\
\hline $\begin{array}{l}\text { Synorisporites downtonensis } \\
\quad \text { (crassitate trilete spore) }\end{array}$ & $\begin{array}{l}\text { elongate spore masses } \\
\text { (Pridoli) }\end{array}$ & homogeneous & Edwards et al. (1996) \\
\hline $\begin{array}{l}\text { Retusotriletes sp. } \\
\quad \text { (retusoid trilete spore) }\end{array}$ & $\begin{array}{l}\text { in situ in Resilitheca } \\
\text { salopensis } \\
\text { (Lochkovian) }\end{array}$ & $\begin{array}{l}\text { faint traces of lamellae. Abundant exosporal } \\
\text { material }\end{array}$ & Edwards et al. $(1995 b)$ \\
\hline $\begin{array}{l}\text { Retusotriletes cf. coronadus } \\
\quad \text { (retusoid trilete spore) }\end{array}$ & $\begin{array}{l}\text { discoidal spore masses } \\
\text { (Pridoli) }\end{array}$ & $\begin{array}{l}\text { narrow inner darker layer and essentially } \\
\text { homogeneous outer layer but with faint striations }\end{array}$ & Edwards et al. (1996) \\
\hline $\begin{array}{l}\text { Apiculiretusispora brandtii } \\
\text { (retusoid trilete spore) }\end{array}$ & $\begin{array}{l}\text { Psilophyton forbesii } \\
\text { (Emsian) }\end{array}$ & $\begin{array}{l}\text { thick inner homogenous layer with a thin outer, } \\
\text { often detachable, layer representing the ornament }\end{array}$ & Gensel \& White (1983) \\
\hline $\begin{array}{l}\text { Tetrahedraletes medinensis } \\
\text { (naked permanent } \\
\text { tetrad) }\end{array}$ & $\begin{array}{l}\text { dispersed } \\
\text { (Ashgill) }\end{array}$ & homogeneous, possibly with subtle lamellation & Taylor (1995) \\
\hline $\begin{array}{l}\text { Pseudodyadospora sp. } \\
\quad \text { (naked pseudodyad) }\end{array}$ & $\begin{array}{l}\text { dispersed } \\
\text { (Ashgill-Llandovery) }\end{array}$ & homogeneous & Taylor (1996) \\
\hline $\begin{array}{l}\text { Dyadospora murusdensa } \\
\text { (naked true dyad) }\end{array}$ & $\begin{array}{l}\text { dispersed } \\
\text { (Ashgill-Llandovery) }\end{array}$ & $\begin{array}{l}\text { bilayered with lamellate inner layer and } \\
\text { homogeneous outer layer }\end{array}$ & Taylor (1996) \\
\hline $\begin{array}{l}\text { Segestrespora membranifera } \\
\text { (envelope-enclosed } \\
\text { dyad) }\end{array}$ & $\begin{array}{l}\text { dispersed } \\
\text { (Ashgill) }\end{array}$ & $\begin{array}{l}\text { homogeneous to somewhat spongy with } \\
\text { irregular globular units and lamellae at the } \\
\text { exterior. Envelope stains darker than wall }\end{array}$ & Taylor (1996) \\
\hline
\end{tabular}

uninformative preserving little morphological-anatomical detail. They comprise elongate sporangia attached to only short lengths of unbranched axis making it impossible to determine if the axis branched. Undissociated dyads have also been reported from latest Silurian-earliest Devonian spore masses and rhyniophytoids (Lang 1937; Fanning et al. 1991; Shute et al. 1996; Wellman et al. 1998). One of the specimens described by Wellman and co-workers clearly comprises a bifurcating axis with terminal sporangia. In the specimens reported here, the absence of an axial branching system, and in some cases sporangial wall, is intriguing. There are a number of possible explanations. Perhaps the vegetative system was succulent and parenchymatous with only limited vascular tissue, similar to that seen in certain Rhynie Chert plants, and thus unlikely to be preserved. On the other hand, low preservation potential is likely if the parent plant was at a bryophytic grade and lacked appropriate recalcitrant polymers. Finally, the sporangial wall may have been thin, with spore masses dispersed on sporangial maturation, suggesting that the spore masses may have been produced by the numerous sterile axes (e.g. Hostinella) that occur in the plant assemblages under consideration.

It is thus evident that comparisons with dyad-producing extant and fossil land plants reveal little regarding the affinities of the specimens under consideration. Among extant plants there appear to be no obvious homologues. Fossils plants with in situ dyads are rare and uninformative owing to the limited morphologicalanatomical detail preserved.

\section{(b) Comparisons with spore wall ultrastructure and related characters in fossil plants}

Spore wall ultrastructure has been examined in few early land-plant spore taxa. Trilete spores have been examined by using in situ material of Pridoli age (Rogerson et al. 1993), Lochkovian age (Edwards et al. 1995a,c, 1996) and Emsian age (Gensel \& White 1983). Retusoid and crassitate miospores have been examined but there are as yet no published accounts of spore wall ultrastructure in patinate trilete spores. Cryptospores have been examined by using dispersed spores of Ashgill and Llandovery age (Taylor 1995a,b, 1996): they include naked pseudodyads, true dyads and tetrads and envelopeenclosed dyads. A summary of the published accounts of ultrastructural characteristics of early land-plant spore taxa is shown in table 3.

Ultrastructure group A (see table 2) has most in common with that in crassitate trilete spore taxa from subspecies of the tracheophyte Cooksonia pertoni Lang 1937 which are bilayered and covered with EEM interpreted as either perispore or possibly fossilized intralocular fluid (Rogerson et al. 1993; Edwards et al. 1995a). Ultrastructure group A is similarly bilayered but lacks the EEM. It is unlikely that its absence is taphonomic, perhaps resulting from leaching in specimens lacking a sporangial wall, as it is preserved in the elongate sporangia even where the spores are completely exposed. Ultrastructure type B is bilayered with abundant EEM. However, it differs from ultrastructure in the spores of $C$. pertoni as the inner layer is lamellate. Taylor (1996) described a similar ultrastructure in the dispersed cryptospore dyad Dyadospora 
Table 4. Synopsis of generalized mature spore wall ultrastructure in extant plants (information derived from Brown \& Lemmon (1990) and Lugardon (1990))

\begin{tabular}{|c|c|c|c|}
\hline group & ultrastructure & extra-exosporal material & elators \\
\hline Hepaticae & $\begin{array}{l}\text { lamellate (may be partly occluded towards } \\
\text { the outside) }\end{array}$ & no & yes \\
\hline Anthocerotae & homogeneous & no & pseudo \\
\hline Musci & $\begin{array}{l}\text { homogeneous except for a narrow lamellate } \\
\text { innermost exospore layer }\end{array}$ & perispore & no \\
\hline Sphenopsida & $\begin{array}{l}\text { bilayered comprising two homogeneous layers } \\
\text { approximately equal in thickness }\end{array}$ & epispore & yes \\
\hline $\begin{array}{l}\text { Lycopsida } \\
\text { (homosporous) }\end{array}$ & $\begin{array}{l}\text { bilayered. Outer layer amorphous, inner layer } \\
\text { comprising short lamellae (often occluded) }\end{array}$ & $\begin{array}{l}\text { usually absent but } \\
\text { occasionally with } 1 \text { or } 2 \\
\text { layered perispore. Some } \\
\text { with globules }\end{array}$ & no \\
\hline $\begin{array}{l}\text { Filicopsida } \\
\text { (homosporous) }\end{array}$ & $\begin{array}{l}\text { thick outer homogeneous layer overlies } \\
\text { a lamellated layer comprising } 1-12 \text { lamellae }\end{array}$ & $\begin{array}{l}\text { perispore. Often with } \\
\text { globules and/or spherules }\end{array}$ & no \\
\hline
\end{tabular}

murusdensa from Late Ordovician-Early Silurian deposits, in which the wall is bilayered with an inner lamellate layer and an outer homogeneous layer. The absence of EEM in Taylor's specimens could have resulted from sloughing off before or during dispersal. There are no obvious counterparts with ultrastructure group $\mathrm{C}$ as the short discontinuous lamellae that characterize this type of ultrastructure have not been reported previously among early land-plant spores. A number of fossil spores have homogeneous ultrastructure similar to that of ultrastructure group D, e.g. tetrads of the crassitate trilete spore Synorisporites downtonensis (Edwards et al. 1996), the cryptospore tetrad Tetrahedraletes medinensis (Taylor 1995a) and the cryptospore dyad Pseudodyadospora sp. (Taylor 1996). However, such simple ultrastructure probably occurs in numerous spores types that are not closely related, and could even be attributed to homogenization from diagenesis. In this case the latter explanation is untenable in view of the delicate ultrastructure recorded in the other types. Ultrastructure group $\mathrm{E}$ resembles that in the spores of $C$. pertoni, i.e. bilayered with EEM. However, in ultrastructure type $\mathrm{E}$ there is no appreciable difference in the staining of the wall layers and the EEM comprises comparatively rare, discrete, particles and does not form a continuous layer.

Although few early land-plant spores have been examined ultrastructurally, it is evident that they exhibit great diversity in spore wall structure. Analysis of relationships between fossil spore morphology and wall ultrastructure suggests that no obvious patterns have been revealed, but this may be a consequence of the limited database. Ultrastructural comparisons between the material described herein and the previously described fossil material is therefore rather tentative. Possibly the most interesting observation is the similarity in spore wall ultrastructure between that in ultrastructure type $\mathrm{B}$ and the cryptospore permanent dyad Dyadospora murusdensa which hints at a relationship between Ashgill-Llandovery permanent dyads and Pridoli hilate cryptospores.

\section{(c) Comparisons with spore wall ultrastructure and related characters in extant plants}

Comparisons with the ultrastructure of spores in extant plants is hampered for two main reasons: (i) in extant plants we can examine variation in ultrastructure throughout spore ontogeny, but in fossils, based on morphological similarities between in situ and mature dispersed spores, and consistency in appearance of in situ spores recovered from examples of the same taxon (see, for example, Rogerson et al. (1993); Edwards et al. $(1995 a)$ ), we conclude that we are usually confined to the analysis of mature spores; and (ii) it is unclear to what extent diagenesis has altered the ultrastructure of fossil spores, although the variation we report and the ultrastructural details preserved suggest that this is not a main constraint. Nevertheless, Late Silurian-Early Devonian plants were probably all homosporous and allow broad comparisons with spores of extant homosporous plants (bryophytes and certain 'pteridophytes'). A summary of ultrastructure present in mature spores of the relevant extant plant groups is shown in table 4 .

\section{(i) Group A}

With the proviso of the unlikelihood of preservation failure, the absence of EEM and therefore an extraexosporal layer (perine, epispore, para-exospore) eliminates mosses, sphenopsids, filicopsids and certain homosporous lycopsids. This leaves the hepatics, anthocerotes and certain homosporous lycopsids for further consideration. Ultrastructurally the fossil spores differ from those of hepatics because the latter usually retain conspicuous lamellae in their walls. Furthermore, most hepatics have elaters which might be expected to be preserved (Kroken et al. 1996). The fossils are similar to anthocerotes in possessing a wall of homogeneous material, although this is unilayered in anthocerotes. Furthermore, anthocerotes have elongate sporangia, elaters and unique sporogenesis involving a columella with the spores maturing sequentially. The fossils are unlikely to have possessed an elongate sporangium, there is no evidence for a columella (although it is not always present at maturity in extant plants) and the spores all appear to be at the same level of maturity. The fossils have a similar wall structure to homosporous lycopsids that lack a perispore, except that in the latter the inner layer often contains evidence of short white-line-centred lamellae, even at maturity (Lugardon 1990). 


\section{(ii) Group B}

The presence of abundant EEM prompts comparisons with mosses, sphenopsids, certain homosporous lycopsids and filicopsids, although there is no discrete layer in the fossils. The fossils bear certain similarities to the Sphagnopsida-type wall (Brown \& Lemmon 1990). The inner lamellate layer may compare with the A layer, the outer homogeneous layer with the B layer and the EEM with the perispore. However, the unique translucent layer comprising unconsolidated exine lamellae in a matrix of unknown composition (Brown \& Lemmon $1990)$ is absent. There are vast ultrastructural differences between the spore walls of the fossils and sphenopsids; the latter have walls comprising two homogeneous layers of approximately equal thickness, an epispore (sensu Lugardon 1990), and a basal layer one-lamella thick. The fossils have a similar wall arrangement to lycopsids but in the latter the lamellae are short and overlapping and not long and continuous as they are in the fossils. The fossils share most similarities with filicopsid spores in which there is a lamellate inner layer, an homogeneous outer layer, and a perispore. The lamellate layer comprises between 1-12 lamellae, but more primitive forms possess more lamellae. Furthermore, the perispore is often rather simple in primitive forms (Lugardon 1990), but may be more complex in more derived taxa.

\section{(iii) Group $C$}

The presence of abundant EEM suggests that most productive comparisons are with the extant plants already considered in group B. A principal difference with both the mosses and sphenopsids is their lack of a multilamellate layer. While the Musci innermost exospore layer may be homologous with the lamellate layer it comprises a single continuous lamella rather than several superimposed short lamellae. The filicopsids have spores with similar organization to the fossils, but the lamellate layer comprises long continuous lamella, rather than short discontinuous ones, and is not usually very thick, comprising 12 or fewer superimposed lamellae. The spore walls in the fossils have most in common with those in homosporous lycopsids some of which possess a perispore. Such lycopsids have a multilamellate inner layer comprising short discontinuous lamellae very similar to those present in the fossils (see, for example, Lycopodium in Lugardon (1990); fig. 4e). This lamellate layer is overlain by a layer of homogeneous sporopollenin; a similar layer in an equivalent position is present in the fossils. It accumulates centripetally and the outer lamellae gradually become compressed and cemented with sporopollenin. In some species they are obscured at maturity, in others conspicuous. There is some evidence that the walls in the fossils also developed centripetally; the inner lamellae are more continuous and clearer than those towards the outside of the exospore.

\section{(iv) Group D}

The absence of EEM suggests that most fruitful comparisons are with the hepatics, anthocerotes and certain homosporous lycopsids. Absence of lamellae and elaters argues against affinities with hepatics. The fossils and anthocerotes both have spore walls which essentially comprise a single homogeneous layer. However, differences in sporangial characteristics mentioned here are against such affinities. The fossil homogeneous spore walls are quite unlike those of homosporous lycopsids (see previous paragraph). Thus there is no extant analogue.

\section{(v) Group E}

In this group the wall clearly comprises two layers, although it is unclear if the outer layer forms part of the exospore or was deposited as an extra-exosporal layer. There is some evidence for the latter because the outer layer is formed of material ultrastructurally similar to that comprising globules of EEM seen between the spores. Whatever the case, the fossil spore walls clearly differ from those in hepatics, anthocerotes and lycopsids, because hepatics have a conspicuously lamellated wall and possibly elaters, anthocerotes have an elongate sporangium with columella, sequentially maturing spores and elaters, and if they were lycopsids one might expect a lamellate inner layer, although it is possible for the lamellae to be fully occluded. However, the fossils share some similarities with Bryopsida-type spore walls (Brown \& Lemmon 1990). Although a foundation layer is not recognized in the fossils, this layer in often very difficult to discern in living plants. The fossils also share some similarities with filicopsid spore walls (Lugardon 1990). However, the fossils lack a foot layer, although in more derived extant ferns this comprises a single lamella and may be rather difficult to discern. Sphenopsids have a homogeneous wall comprising two layers of equal thickness and an epispore (sensu Lugardon 1990). The fossils are clearly a layer short, lacking either the epispore or one exospore layer depending on whether the outer layer is interpreted as an extra-exosporal or exospore layer.

\section{(d) Conclusions}

The L. divellomedia-containing mesofossils described in this study can, on the basis of sporangium-spore morphological and ultrastructural characters, be divided into five groups $(\mathrm{A}-\mathrm{E})$. Each group possesses a different combination of characters as well as certain unique features. None compare well with described Late Silurian-Early Devonian representatives. However, comparisons are hampered because for this interval: (i) relatively few fossil plants are known; (ii) in situ spores are known in only a limited number of these plants; and (iii) very few spores have been studied ultrastructurally. Nor can any of these groups be comfortably accommodated in any group of extant homosporous plants, although it might be argued that there are greater similarities with lycopsids and filicopsids than with bryophytes. This is surprising based on the geological occurrence of dyads, inferences on the producers being at a bryophyte grade of organization, and the simplicity of the dyad-containing fossils. Unfortunately the lack of recognizable lycopsid spores in the latest Silurian-earliest Devonian rules out comparisons. However, even if the producers were to be closely related to any living groups, it is unclear to what extent character combinations of modern representatives of a group differ from their distant ancestors. 


\section{COMMENTS ON SPORE WALL DEVELOPMENT}

Perhaps the most important result of this study has been the demonstration of the preservation of white-linecentred lamellae in a 400-million-year-old fossil. Sporopollenin deposition on white-line-centred lamellae has been reported in the zygote walls of charophycean algae, the presumed sister group to all land plants (the embryophytes), in addition to the spore-pollen walls of all principal groups of land plants (bryophytes, 'pteridophytes', gymnosperms and angiosperms). These findings have led to the hypothesis that the structures and processes involved in this mode of sporopollenin deposition are, in all cases, homologous and it is the most primitive mode of sporopollenin deposition in cell walls (see, for example, Blackmore \& Barnes (1987) and references therein). The new fossil evidence therefore confirms predictions based on the systematic analysis of extant plants.

Sporopollenin deposition on white-line-centred lamellae is believed to involve sheets of membrane separating from the plasma membrane at the cell surface and then acting as sites for sporopollenin accretion and polymerization (see, for example, Brown \& Lemmon 1990; Lugardon 1990). The sporopollenin may derive from the haploid gametophyte and/or the diploid sporophyte. However, although white-line-centred lamellae always seem to originate in more or less the same way, their subsequent development varies considerably, resulting in a variety of different wall types in different plant groups. This variation is compounded because more derived plant groups also use other modes of sporopollenin deposition, e.g. that directly from the tapetum.

In certain charophycean algae the white-line-centred lamellae converge and merge forming a single continuous lamella that surrounds the entire cell (see, for example, Atkinson et al. 1972). However, in bryophytes the wall may comprise numerous, evenly spaced, superimposed white-line-centred lamellae, e.g. five in the hepatic Scapania nemorosa (Rowley \& Southworth 1967; Steinkamp \& Doyle 1979, 1981, 1984). In the spore walls of certain other plants, e.g. the lycopsid Lycopodium, the white-linecentred lamellae do not converge and merge, and further sporopollenin is deposited unevenly on the membranes resulting in a wall comprising short, overlapping whiteline-centred lamellae that are not equidistant. Consideration of plant phylogeny (charophycean algae are the sister group to embryophytes (bryophytes and tracheophytes) and bryophytes are the sister group to tracheophytes) and the distribution of different modes of sporopollenin deposition suggests that continuous lamellae are the ancestral type but the acquisition of more numerous, superimposed, white-line-centred lamellae was an early feature in the evolution of spore wall formation. However, formation on short, overlapping white-line-centred lamellae is probably a derived condition with respect to continuous white-line-centred lamellae.

Recognition of white-line-centred lamellae in extant plants is often difficult for a number of reasons: (i) they may become compressed together to a greater or lesser extent and even eventually obliterated resulting in a mature wall in which the lamellae are no longer visible; (ii) repeated or continuous sporopollenin deposition may mask initial lamellate structures; and (iii) in more derived plants, where other modes of sporopollenin deposition have become important, white-line-centred lamellae may not be the primary mode of sporopollenin deposition and may be inconspicuous. Furthermore, in fossil plants, except where preservation is exceptional, it seems highly likely that evidence for white-line-centred lamellae might be obliterated during diagenesis.

Our discovery of white-line-centred lamellae in the spore walls of an Early Devonian plant (specimen NMW96.30G.5) demonstrates that such elusive structures can be preserved in ancient fossils. This is the earliest report of such structures and provides evidence for the antiquity of this mode of sporopollenin deposition. However, the white-line-centred lamellae in this specimen comprise laterally discontinuous forms which are not equidistant. Such lamellae are believed to be relatively advanced when compared with the continuous evenly spaced lamellae reported from charophycean algae and bryophytes. It is unclear at was stage in plant phylogeny such lamellae evolved although they clearly occur in certain extant 'pteridophytes' (see previous paragraph). In addition, the occurrence of such an advanced mode of spore wall formation in earliest Devonian plants suggests a significant evolution and diversification among land plants before the Early Devonian. This is perhaps to be expected. Fossil evidence suggests that the earliest land plants, which are believed to have been at a bryophyte-like grade of organization, evolved from the green algae in the Llanvirn (Ordovician), 70 million years previously, thus providing ample time for the evolution of more complex modes of spore wall formation by the Early Devonian. Taylor (1996b) has reported relatively thick parallel-arranged lamellae (but without evidence for tripartite structure) in latest Ordovician cryptospore dyads, which might reflect an earlier, perhaps less derived, mode of sporopollenin deposition.

There is strong evidence that in at least three of the taxa (groups B, C and E) sporopollenin derived from the tapetum (i.e sporophyte) in addition to the sporocyte. Pacini (1990) in a comprehensive review of the morphology, function and evolution of tapetum in land plants argued its ubiquitous presence as a specialized tissue for spore nutrition and probably the source of sporopollenin precursors. However, its presence may be transitory and hence difficult to recognize, particularly in many lower land plants (Brown \& Lemmon 1990). In early land-plant fossils, it can only be inferred, for example if EEM, believed to be derived from a tapetum, is present (Edwards et al. 1995a,c). Of the two principal types of tapetum (cellular and amoeboid), it is likely that early land plants possessed the former. The main advantage of a cellular tapetum is that it allows the production of numerous spores in large sporangia. Among extant plants, bryophytes and most homosporous 'pteridophytes' have a cellular tapetum, although some, for example Equisetum, have an amoeboid one (Pacini 1990). Pacini (1990) also notes that a cellular tapetum is dominant among angiosperms that produce pollen in polyads, suggesting that this type of tapetum is more successful in nourishing polyads. 
Envelope-enclosed cryptospores are common from the Llanvirn (Ordovician)-Llandovery (Early Silurian), but are rare thereafter (Gray 1985; Strother 1991; Strother et al. 1996; Richardson 1996a; Wellman 1996). The thin membraneous envelopes may be loose or tight fitting and are laevigate or ornamented. Their composition is unknown but their recalcitrant nature suggests that they may comprise sporopollenin. All three morphotypes (monads, dyads and tetrads) may occur within envelopes with identical ornament. It has previously been suggested that the envelopes may comprise tapetally derived material that is deposited around the cryptospore unit, be it a monad, dyad or tetrad (Gray 1991). The presence of suspected tapetally derived layers, that in the case of group B specimens appear to surround the entire dyad, points to homologies with the envelope-enclosed cryptospores.

Finally, consideration should be given to the possibility that the various types represent ontogenetic stages of the same spore, although we discount this for the Silurian representatives as sporangial shape (elongate against discoidal) is quite different. For the Lower Devonian spores, where the spore masses-sporangia are all discoidal it might be argued that type $\mathrm{D}$ comprising the largest spores with homogeneous thick walls represents the mature condition of either type $\mathrm{G}$ or $\mathrm{E}$, or alternatively that $\mathrm{C}, \mathrm{E}$ and $\mathrm{D}$ are a single ontogenetic sequence. Because we believe, from examination of a large number of sporangia, that maturation was synchronous, we are unable to obtain ontogenetic details from a single sporangium, and we have insufficient numbers of specimens to evaluate variation. However, we are of the opinion that the spore masses-sporangia contain mature spores. In this study the separated products of the dyad can be linked to dispersed forms within the Laevolancis divellomedia complex, and thus we are convinced that the spores derive from different plants.

\section{EVOLUTIONARY TRENDS AND DIVERSITY}

\section{(a) Separation}

The stratigraphical distribution of dyad morphotypes and the hilate cryptospores that derive from certain dyads is outlined here. Following their inception in the Early Wenlock, hilate cryptospore abundance gradually increases whereas that of undissociated dyads gradually diminishes, although both morphotypes coexist until at least the end of the Lochkovian. It is thus likely that some of the post-Llandovery undissociated dyads were produced by hilate cryptospore-producing plants and represent spores that have uncharacteristically failed to dissociate. Others clearly were not, and are probably related to the older dyads which were habitually dispersed intact, and the relationship of which to hilate cryptospores is unclear. If indeed the dyad-hilate cryptospore producers formed part of a lineage it would suggest that with time there was a tendency for dyad producing plants to disperse their spores dissociated. Analysis of variation in spore-wall ultrastructure, particularly at the critical Late Llandovery-Early Wenlock interval, may prove valuable in ascertaining the relationships between undissociated dyads and hilate cryptospores.

\section{(b) Size variation}

L. divellomedia is commonly found in assemblages of dispersed spores from the Early Wenlock (Silurian)Lochkovian (Early Devonian), and morphologically similar spores are known to extend up into at least the Late Devonian (Balme 1988). A feature of this longranging spore taxon is an increase in average and maximum size of dispersed spores with time. Specimens of Early Wenlock age from Scotland and southern Britain measure 28(36)46 $\mu \mathrm{m}$ (Wellman \& Richardson 1993) and $30(38) 49 \mu \mathrm{m}$ (Burgess \& Richardson 1991), respectively. By the Early Lochkovian specimens from Scotland and southern Britain measure $37(49) 58 \mu \mathrm{m}$

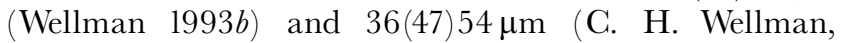
unpublished data) respectively. All of the specimens (groups A and B) from Ludford Lane (Pridoli) contain spores of similar size $(17-32 \mu \mathrm{m}$ in diameter), which are of similar dimensions to those from the Early Wenlock, but at the smaller end of the scale. The specimens from North Brown Clee Hill (Lochkovian) contain larger spores (group $\mathrm{C}$ mean diameter $=36 \mu \mathrm{m}$; group D mean diameter $=53 \mu \mathrm{m}$; group $\mathrm{E}$ mean diameter $=33 \mu \mathrm{m})$. The group D spores are similar in size to those from coeval dispersed spore assemblages from southern Britain and Scotland but the group $\mathrm{C}$ and E spores, although larger than those from Ludford Lane, are rather smaller than expected.

\section{(c) Diversity among the specimens}

All of the specimens described herein contain spores that are morphologically similar, and if found dispersed might be placed in the same spore taxon, unless studied very closely using exceptionally preserved material. However, detailed analysis of morphological, anatomical and ultrastructural characters of the in situ spores and the sporangia-spore masses in which they occur reveals subtle differences between the specimens and these can be correlated with presumed overall sporangium shape. We have divided them into five groups $(\mathrm{A}-\mathrm{E})$ that clearly represent at least five different parent plant taxa (table 2). As the different morphological-ultrastructural characters occur in specimens from the same horizon treated in exactly the same way it can be concluded that the differences are real and not a consequence of differences in diagenetic history or study techniques. Detailed studies are now needed on well-preserved and diverse spore assemblages (see, for example, Richardson 1996b) to identify our five groups in the dispersed-spore record.

\section{(d) Early land-plant diversity}

Laevigate hilate cryptospores have simple morphology with few morphological characters available to distinguish between them. It has long been suspected that such spores are often 'lumped' together in the dispersedspore taxon L. divellomedia, particularly when preservation is mediocre and subtle differences in shape and structure are not readily discernible. It seems highly probable that such spores were produced by a variety of plants that were not necessarily closely related. This seems to be borne out by our work. Such findings reveal hidden diversity among early land plants. It has long been recognized that during the Silurian-Devonian the 
number of plant megafossil taxa is vastly exceeded by the number of dispersed-spore taxa. This is usually attributed to the poor fossil record of early land-plant megafossils. In addition, it has recently been demonstrated that morphologically similar plant fossils may contain different spores attributable to a number of dispersed taxa (Fanning et al. 1988). Consequently the early land-plant dispersed-spore record is usually regarded as being more representative of early land-plant diversity than the megafossil record. Our findings suggest that, in addition, a single dispersed-spore taxon may have had a number of sources with the implication that diversity of early landplants may be underestimated even in counts of dispersed-spore taxa.

\section{CONCLUSIONS}

Studies of spore wall ultrastructure in early land-plant fossil spores are providing a wealth of new information on early land-plants. Such studies help us understand the gross structure of the spores as well as providing information on their wall ultrastructure. The new information is useful for clarifying the taxonomy of early land-plant spores and associated megafossils, and is revealing hidden diversity among early land plants. New characters revealed by this research also provide further evidence useful in determining the affinities of such fossils and testing proposed phylogenetic relationships. Finally, ultrastructural studies provide information on the construction of early land-plant spore walls permitting consideration of spore wall ontogeny and development in early land plants. However, much of the discussion and resulting conclusions are rather tentative owing to the paucity of data on fossil and, to a lesser extent, on extant land-plant spores.

Financial support from the Leverhulme Trust (D.E., senior research fellow, and C.H.W., postdoctoral research associate), the NERC (Research Grant GR9/1441) and the Royal Society (equipment grant) is gratefully acknowledged. Sections were cut by Mike Turner. We thank the following people for help in the early stages of the project: Una Fanning, Ian Glasspool, Martin Holmes and Catherine Rogerson. Dr Steve Blackmore and Dr John Richardson provided invaluable discussion during the preparation of this paper.

\section{REFERENCES}

Atkinson, A. W., Gunning, B. E. S. \& John, P. C. L. 1972 Sporopollenin in the cell wall of Chlorella and other algae: ultrastructure, chemistry, and incorporation of ${ }^{14} \mathrm{C}$-acetate, studied in synchronous cultures. Planta 107, 1-32.

Ball, H. W. \& Dineley, D. L. 1961 The Old Red Sandstone of Brown Clee Hill and the adjacent area. 1. Stratigraphy. Bull. Brit. Mus. Nat. Hist. Geol. 5, 175-242.

Balme, B. 1988 Miospores from Late Devonian (Early Frasnian) strata, Carnarvon Basin, Western Australia. Palaeontographica B 209, 109-166.

Blackmore, S. \& Barnes, S. H. 1987 Embryophyte spore walls: origin, homologies and development. Cladistics 3, 185-195.

Brown, R. C. \& Lemmon, B. E. 1990 Sporogenesis in bryophytes. In Microspores: evolution and ontogeny (ed. S. Blackmore \& R. B. Knox), pp. 55-94. London: Academic Press.

Burgess, N. D. \& Richardson, J. B. 1991 Silurian cryptospores and miospores from the type Wenlock area, Shropshire, England. Palaeontology 34, 601-628.
Chibrikova, E. V. 1959 Spores of the Devonian and older rocks of Bashkiria. In Data on palaeontology and stratigraphy of Devonian and older deposits of Bashkiria, pp. 3-116. Moskva: Izdatel'stvo Akademii Nauk SSSR, Bashkirian Branch. (In Russian.)

Edwards, D. 1996 New insights into early land ecosystems: a glimpse of a Lilliputian world. Rev. Palaeobot. Palynol. 90, 159-174.

Edwards, D., Fanning, U. \& Richardson, J. B. 1986 Stomata and sterome in early land plants. Nature 323, 438-440.

Edwards, D., Davies, K. L. \& Axe, L. 1992 A vascular conducting strand in the early land plant Cooksonia. Nature 357, 683-685.

Edwards, D., Fanning, U. \& Richardson, J. B. 1994 Lower Devonian coalified sporangia from Shropshire: Salopella Edwards \& Richardson and Tortilicaulis Edwards. Bot. F. Linn. Soc. 116, 89-110.

Edwards, D., Davies, K. L., Richardson, J. B. \& Axe, L. 1995a The ultrastructure of spores of Cooksonia pertoni. Palaeontology 38, 153-168.

Edwards, D., Duckett, J. G. \& Richardson, J. B. 1995b Hepatic characters in the earliest land plants. Nature 374, 635-636.

Edwards, D., Fanning, U., Davies, K. L., Axe, L. \& Richardson, J. B. 1995c Exceptional preservation in Lower Devonian coalified fossils from the Welsh Borderland: a new genus based on reniform sporangia lacking thickened borders. Bot. F. Linn. Soc. 117, 233-254.

Edwards, D., Selden, P. A., Richardson, J. B. \& Axe, L. 1995d Coprolites as evidence for plant-animal interaction in SiluroDevonian terrestrial ecosystems. Nature 377, 329-331.

Edwards, D., Davies, K. L., Richardson, J. B., Wellman, G. H. \& Axe, L. 1996 Ultrastructure of Synorisporites downtonensis and Retusotriletes cf. coronadus in spore masses from the Pridoli of the Welsh Borderland. Palaeontology 39, 783-800.

Fanning, U., Richardson, J. B. \& Edwards, D. 1988 Cryptic evolution in early land plants. Evol. Trends Pl. 2, 13-24.

Fanning, U., Richardson, J. B. \& Edwards, D. 1991 A review of in situ spores in Silurian land plants. In Pollen and spores: patterns of diversification (ed. S. Blackmore \& S. H. Barnes), pp. 25-47. Systematics Association Special Volume No. 44. Oxford: Clarendon Press.

Gensel, P. G. \& White, A. R. 1983 The morphology and ultrastructure of spores of the Early Devonian trimerophyte Psilophyton (Dawson) Hueber and Banks. Palynology 7, 221-233.

Gray, J. 1985 The microfossil record of early land plants: advances in understanding of early terrestrialization, 19701984. Phil. Trans. R. Soc. Lond. B 309, 167-195.

Gray, J. 1991 Tetrahedraletes, Nodospora, and the 'cross' tetrad: an accretion of myth. In Pollen and spores: patterns of diversification (ed. S. Blackmore \& S. H. Barnes), pp. 49-87. Systematics Association Special Volume No. 44. Oxford: Clarendon Press.

Gray, J. 1993 Major Paleozoic land plant evolutionary bioevents. Palaeogeog. Palaeoclimatol. Palaeoecol. 104, 153-169.

Hemsley, A. R. 1994 The origin of the land plant sporophyte: an interpolational scenario. Biol. Res. 69, 263-273.

Jeram, A. J., Selden, P. A. \& Edwards, D. 1990 Land animals in the Silurian: arachnids and myriapods from Shropshire, England. Science 250, 658-661.

Kroken, S. B., Graham, L. E. \& Cook, M. E. 1996 Occurrence and evolutionary significance of resistant cell walls in charophytes and bryophytes. Am. F. Bot. 83, 1241-1254.

Lang, W. H. 1937 On the plant-remains from the Downtonian of England and Wales. Phil. Trans. R. Soc. Lond. B 227, 245-291.

Lugardon, B. 1990 Pteridophyte sporogenesis: a survey of spore wall ontogeny and fine structure in a polyphyletic plant group. In Microspores: evolution and ontogeny (ed. S. Blackmore \& R. B. Knox), pp. 95-120. London: Academic Press. 
Pacini, E. 1990 Tapetum and microspore function. In Microspores: evolution and ontogeny (ed. S. Blackmore \& R. B. Knox), pp. 213-238. London: Academic Press.

Richardson, J. B. 1996a Lower and Middle Palaeozoic records of terrestrial palynomorphs. In Palynology: principles and applications (ed. J. Jansonius \& D. C. McGregor), pp. 555-574. Salt Lake City, UT: American Association of Stratigraphic Palynologists Foundation.

Richardson, J. B. $1996 b$ Taxonomy and classification of some new Early Devonian cryptospores from England. Spec. Pap. Palaeont. 55, 7-40.

Richardson, J. B. 1996c Abnormal spores and possible interspecific hybridization as a factor in the evolution of Early Devonian land plants. Rev. Palaeobot. Palynol. 93, 333-340.

Richardson, J. B. \& McGregor, D. C. 1986 Silurian and Devonian spore zones of the Old Red Sandstone continent and adjacent regions. Geol. Surv. Can. Bull. 364, 79pp.

Richardson, J. B. \& Rasul, S. M. 1990 Palynofacies in a Late Silurian regressive sequence in the Welsh Borderland and Wales. F. Geol. Soc. Lond. 147, 675-686.

Rogerson, E. C. W., Edwards, D., Davies, K. L. \& Richardson, J. B. 1993 Identification of in situ spores in a Silurian Cooksonia from the Welsh Borderland. Spec. Pap. Palaeont. 49, 17-30.

Rowley, J. R. \& Southworth, D. 1967 Deposition of sporopollenin on lamellae of unit membrane dimensions. Nature 213, 703-704.

Shute, C. H., Hemsley, A. R. \& Strother, P. K. 1996 Reassessment of dyads contained in a late Silurian rhyniophytoid sporangium. Spec. Pap. Palaeont. 55, 137-145.

Steinkamp, M. P. \& Doyle, W. T. 1979 Spore wall ultrastructure in four species of the liverwort Riccia. Am. F. Bot. 66, 546-556.

Steinkamp, M. P. \& Doyle, W. T. 1981 Spore wall ultrastructure in the liverwort Athalamia hyalina. Am. F. Bot. 68, 395-401.

Steinkamp, M. P. \& Doyle, W. T. 1984 Spore wall ultra structure in the liverwort Fossombronia longiseta. Can. F. Bot. 62, 1871-1879.
Strother, P. K. 1991 A classification schema for cryptospores. Palynology 15, 210-236.

Strother, P. K., Al-Hajri, S. \& Traverse, A. 1996 New evidence for land plants from the lower Middle Ordovician of Saudi Arabia. Geology 24, 55-58.

Taylor, W. A. 1995a Ultrastructure of Tetrahedraletes medinensis (Strother and Traverse) Wellman and Richardson, from the Upper Ordovician of southern Ohio. Rev. Palaeobot. Palynol. 85, 183-187.

Taylor, W. A. $1995 b$ Spores in earliest land plants. Nature 373, 391-392.

Taylor, W. A. 1996 Ultrastructure of lower Paleozoic dyads from southern Ohio. Rev. Palaeobot. Palynol. 92, 269-279.

Wellman, C. H. 1993a A Lower Devonian sporomorph assemblage from the Midland Valley of Scotland. Trans. R. Soc. Edinb. 84, 117-136.

Wellman, C. H. $1993 b$ A land plant microfossil assemblage of Mid Silurian age from the Stonehaven Group, Scotland. $\mathcal{F}$. Micropalaeont. 12, 47-66.

Wellman, C. H. 1996 Cryptospores from the type area of the Caradoc Series in southern Britain. Spec. Pap. Palaeont. 55, 103-136.

Wellman, C. H. \& Richardson, J. B. 1993 Terrestrial plant microfossils from Silurian inliers of the Midland Valley of Scotland. Palaeontology 36, 155-193.

Wellman, C. H., Edwards, D. \& Axe, L. 1996 Curation of exceptionally preserved early land plant fossils: problems and solutions. Curator 39, 208-216.

Wellman, C. H., Edwards, D. \& Axe, L. 1998 Permanent dyads in sporangia and spore masses from the Lower Devonian of the Welsh Borderland. Bot. F. Linn. Soc. 127, 117-147.

White, D. E. \& Lawson, J. D. 1989 The Pridoli Series in the Welsh Borderland and south-central Wales. In A global standard for the Silurian System (ed. C. H. Holland \& M. G. Bassett), pp. 131-141. Geological Series no. 9. Cardiff: National Museum of Wales. 